\title{
Grammaticalization of subject agreement on evidence from Italo-Romance
}

DOI:

10.1515/ling-2018-0022

\section{Document Version}

Accepted author manuscript

Link to publication record in Manchester Research Explorer

\section{Citation for published version (APA):}

Bentley, D. (2018). Grammaticalization of subject agreement on evidence from Italo-Romance. Linguistics, 56(6), 1245-1301. https://doi.org/10.1515/ling-2018-0022

\section{Published in:}

Linguistics

\section{Citing this paper}

Please note that where the full-text provided on Manchester Research Explorer is the Author Accepted Manuscript or Proof version this may differ from the final Published version. If citing, it is advised that you check and use the publisher's definitive version.

\section{General rights}

Copyright and moral rights for the publications made accessible in the Research Explorer are retained by the authors and/or other copyright owners and it is a condition of accessing publications that users recognise and abide by the legal requirements associated with these rights.

\section{Takedown policy}

If you believe that this document breaches copyright please refer to the University of Manchester's Takedown Procedures [http://man.ac.uk/04Y6Bo] or contact uml.scholarlycommunications@manchester.ac.uk providing relevant details, so we can investigate your claim.

\section{OPEN ACCESS}




\section{Delia Bentley}

\section{Grammaticalization of subject agreement on evidence from Italo- Romance}

Abstract: In this paper we consider the grammaticalization of subject agreement adducing first-hand synchronic evidence from presentational VS constructions in Italo-Romance dialects. While the existing literature has placed emphasis on the pragmatic properties of the controller, we explore its semantic properties. We argue that variation in subject agreement can only be fully captured with reference to an independently established semantic scale of subjecthood that is based on the position of arguments in semantic representation, and hence on their lexical entailments (Jackendoff 1976; Dowty 1991; Van Valin and LaPolla 1997). Unaffected actor is the default controller in accusative alignment.

The patterns of dialect microvariation arise, in our analysis, from parametric variation in macrorole assignment in presentational focus. Our proposal formalizes at the discoursesemantics-syntax interface the idea that, in presentational VS constructions, the core argument S may be treated as part of the predicate, thus failing to control grammatical subject agreement (Fuchs 1980). This happens in presentational focus because the predication is about an implicit topic (Benincà 1988, among others). The latter can trigger a type of pronominal agreement that is comparable to Bresnan and Mchombo's (1987) anaphoric agreement.

This study provides robust arguments in support of an understanding of subject agreement as the grammaticalization of semantic-relation contrasts, as well as pragmatic-role distinctions.

Keywords: subject agreement, macrorole, presentational construction, implicit topic, anaphoric agreement, dialect microvariation.

\section{Introduction}

It has long been known that if, in a given language, the verb agrees with a following argument in a given syntactic function, it will also agree with a preceding argument in the same syntactic function (Moravcsik 1978). Lehmann (2014 [1982]: 50) links this implicational relation to the diachronic derivation of grammatical agreement from anaphoric agreement (Givón 1976; Siewierska 1999; Corbett 2003; Mithun 2003, among others). Since anaphoras normally follow their antecedent, verb agreement first grammaticalizes in SV order. Then it may become optional and, finally, obligatory in VS order, where anaphora is "difficult" [sic.]. Therefore, in synchrony, verb agreement with post-verbal subjects entails verb agreement with pre-verbal subjects.

The sensitivity of subject agreement to word order is observed in Italo-Romance, a family of Romance languages that include Italian and are primarily spoken in Italy. ${ }^{1}$ While finite (i.e., person and number) agreement of the verb with a preceding subject is generally obligatory in

\footnotetext{
Corresponding author: Delia Bentley, Linguistics and English Language, School of Arts, Languages and CuE-mail: delia.bentley@manchester.ac.uk

${ }^{1}$ These are Romance languages in their own right and not varieties of Italian, the standard language of Italy. They are conventionally referred to as dialects because they have very little, if any, socio-political recognition. For further detail, including the classification of these languages into different subfamilies, we refer to Maiden and Parry (1997).
} 
this language family, extensive cross-dialectal variation is observed in VS order. This variation has received a great deal of attention in syntactic research (Burzio 1986; Brandi and Cordin 1989; Manzini and Savoia 2005; Rizzi 1986; Roberts 2014; Saccon 1992, 1993; Samek-Lodovici 2002, among others). The existing treatments point out that, in many northern dialects, number agreement of the verb with a following argument in subject function varies in accordance with verb class in a way that is reminiscent of the unaccusative-vs.-unergative divide (see Parry 1997: 243, 2000, 2013; Savoia 1997: 232; Tortora 1997, 2014; Cardinaletti and Repetti 2010: 131-133; for the Unaccusative Hypothesis see Perlmutter 1978, 1989; Burzio 1986). However, the extent of this variation is poorly understood, and whether its rationale is unaccusativity is a moot point. Whether person varies alongside number agreement is also debated.

In this paper we study the grammaticalization of subject agreement in light of fresh evidence from Italo-Romance. ${ }^{2}$ With the term grammaticalization we mean the extent to which subject agreement is grammaticalized and hence unaffected by pragmatic or semantic properties of the controller. While the existing literature has placed emphasis on pragmatic properties of the controller, for example topicality (Givón 1976; Bresnan and Mchombo 1987; Lehmann 1982, 2014), we explore the interaction of discourse with the semantics of the source of agreement, which ultimately depends on the semantics of the predicate (Dowty 1991)..$^{3}$

We refer to person and number agreement of the verb with a preceding pronoun or noun phrase subject as $\mathrm{S}-\mathrm{V}$ agreement. With $\mathrm{V}-\mathrm{S}$ agreement, instead, we refer to person and number agreement of the verb with a following pronoun or noun phrase. Unlike $\mathrm{S}-\mathrm{V}$ agreement, V-S agreement is not fully grammaticalized in all the Italo-Romance dialects. We identify and describe three principal patterns of $\mathrm{V}-\mathrm{S}$ agreement. In pattern (i) $\mathrm{V}-\mathrm{S}$ agreement is fully grammaticalized. Thus, the verb agrees systematically with a post-verbal argument in subject function, or, in the absence of an argument, with a non-argumental noun phrase endowed with agreement features. This is the case with existential there-sentences, where the post-copular noun phrase is not an argument (Francez 2007, among others). ${ }^{4}$

\footnotetext{
${ }^{2}$ This evidence was collected by the author in the period between November 2014 and June 2015. The survey included nine Gallo-Italian dialects spoken in the North of Italy (Grosio, Limbiate, Milan, Scanzorosciate in Lombardy; Asti, Fontanelle di Boves, Oglianico, Turin in Piedmont; Cairo Montenotte in Liguria). However, for ease of exposition, we shall normally only provide evidence from four of these dialects: Cairo, Milan, Fontanelle and Grosio. Thanks are due to the School of Arts, Languages and Cultures of the University of Manchester, for sponsoring the fieldwork with the Research Support Fund, and to our informants and helpers in the field: in particular, Giuliano Bernini, Valeria Figini, Alberto Ghia, Paolo Ghinamo, Mair Parry, Alda Rossebastiano, Tullio Telmon, and Massimo Vai. See Section 2 (note 6) for a brief discussion of the methodology adopted in the field research. We are also grateful to the participants of the $49^{\text {th }}$ Conference of the Societas Linguistica Europaea (University of Naples Federico II, 31 August to 3 Setember 2016) for helpful comments on this research.

${ }^{3}$ With the term source, we refer to the candidate for - or potential controller of - subject agreement in the clause. As will become clear, the source does not control agreement under conditions to be explored in the paper. For the terms controller, target, domain and feature we refer to Corbett (2006: 4-5). The controller is the element which determines the agreement features; the target is the element whose form is determined by agreement; the domain is the syntactic environment in which agreement occurs; features are the properties according to which there is covariance between controller and target.

4 The Leipzig abbreviations (http://www.eva.mpg.de/lingua/resources/glossing-rules.php) are used in the glosses of the examples, with the following additions: ACL $=$ anaphoric clitic, ESCL $=$ expletive subject clitic, IOCL $=$ indirect object clitic; $\mathrm{LCL}=$ locative clitic; $\mathrm{LOC}=$ locative; OCL $=$ object clitic; $\mathrm{SCL}=$ subject clitic; SUPERL = superlative. The anaphoric clitic will be discussed at length in the paper. An expletive subject clitic is a clitic that occurs in meteorological and presentational constructions, where it has default gender, person or number features; some such clitics belong to the subject clitic paradigm of the relevant dialect (e.g., Cairese $u$ ), while others do not have subject behaviour (e.g., Northern $a$, see Benincà 1983; Bernini 2012).
} 
(1) Italian

\author{
Ci sono bambini sfortunati. \\ ACL be.3PL children.MPL unlucky.MPL \\ 'There are unlucky children.'
}

In pattern (ii), the copula fails to agree with the post-copular noun phrase of there-sentences. In a sub-group of these dialects, which we call (iia), V-S agreement is instead the norm if the verb is contentful. In another subgroup, which we call (iib), V-S agreement is optional with intransitive state-based predicates (states, achievements and accomplishments, see Vendler 1967; Van Valin and LaPolla 1997: 91-92) and obligatory with non-state-based ones (intransitive activities). We will discuss these two predicate classes in Section 3. In this context the reader should note that the contrast under discussion would at first seem to correspond to an unaccusativity split. Lastly, pattern (iii) bans V-S agreement with intransitive state-based predicates, while allowing it with activities.

Our dialect findings challenge the hypothesis that $\mathrm{V}-\mathrm{S}$ agreement in northern dialects is a straightforward unaccusative-vs.-unergative diagnostic. Building upon Parry (2013) (see also Ciconte 2010), we propose that, as a result of the development of subject clitics, a number of dialects exhibit a synchronic conflict in verb agreement with, on the one hand, a semantically unspecified and discourse-dependent spatio-temporal modifier of the predication and, on the other, a clause-internal argument endowed with person and number features. The former type of agreement resembles Bresnan and Mchombo's (1987) anaphoric agreement to the extent that it involves a discourse-dependent antecedent. This can be considered to be a topic insofar as it is discourse-dependent and understood. Contrastingly, the latter type of agreement corresponds to Bresnan and Mchombo's (1987) notion of grammatical agreement, in that the source is a clause-internal subject endowed with person and number features. ${ }^{5}$ When the source of grammatical agreement is focal, and hence does not precede the target, while also ranking below the dialect-specific threshold on a semantic scale of subjecthood (Van Valin and LaPolla 1997: 175; Van Valin 2005), it may fail to receive a macrorole and thus to control grammatical agreement. Instead, anaphoric agreement with a semantically unspecificed and discourse-dependent spatio-temporal modifier of the predication is spelled out by an etymologically locative bound pronoun in subject-clitic position ( $g$ he in 2 ).

(2) Milan, Lombardy
Gh' è mort tanti suldà.
ACL be.3SG died many.MPL soldier.MPL
'There died many soldiers.'

The structure exemplified in (2) only occurs in northern dialects because these are subjectclitic dialects, i.e., dialects in which verb agreement can be spelled out on a bound pronominal form called subject clitic.

Our proposal formalizes the insight that, in presentational constructions, a core argument may be treated as part of the predicate, thus failing to behave as the controller of subject agreement (Fuchs 1980: 449; Sasse 2006: 258; see also Lambrecht 2000; Zeller 2013). The

\footnotetext{
${ }^{5}$ Anaphoric agreement differs from grammatical agreement, insofar as it is not clause-internal, or defined in terms of a syntactic configuration, and it is spelled out on a bound pronoun whose antecedent is a topic. Grammatical agreement, on the other hand, is clause internal agreement with a subject and can be spelled out inflectionally and/or on a bound pronoun. The reader should note that following Bresnan and Mchombo (1987), we do not use the terms anaphora and anaphoric in the sense of Binding Theory, that is, to refer to reflexive pronouns. We call antecedent the element that provides the meaning or the agreement features of a proform. We call anaphora the proform that spells out the meaning or the agreement features of the antecendent.
} 
treatment of a core argument as part of the predicate is found in presentational focus because this type of focus structure presupposes an implicit topic (Benincà 1988; Saccon 1992, 1993; Erteschik-Shir 1997; Pinto 1997; Tortora 1997, 2014; Manzini and Savoia 2005; Parry 2013; Corr 2016). It is because of this implicit topic that the competition between anaphoric and grammatical agreement arises.

The semantic scale of subjecthood which subject agreement is sensitive to is based on the position of the arguments in the semantic representation of the predicate (Van Valin and LaPolla 1997: 175; Van Valin 2005) and can informally be represented as follows.

(3) Argument of agentive activity $>1$ st argument of non-agentive activity $>1$ st argument of state predicate $>2$ nd argument of state predicate $>$ only argument of state predicate $>$ non-argumental noun phrase.

The principal prediction that arises from our analysis is that agreement with each of the argument positions on the scale in (3) entails agreement with those to its left, but not with those to its right. In the last analysis our results contribute to an understanding of subject agreement as the synchronic grammaticalization - or neutralization - of both pragmatic-role and semantic-relation distinctions. Our findings also support Bresnan and Mchombo's (1987) seminal work on anaphoric and grammatical agreement.

The paper is organized as follows. After some necessary preliminaries (Section 2.1), we provide a fully-fledged description of the patterns that we found in Italo-Romance (Section 2.2). In Section 3, we introduce the theoretical underpinnings of the analysis. In Section 4, we evaluate the hypothesis that the variation in $\mathrm{V}-\mathrm{S}$ agreement attested in northern dialects of Italy be a manifestation of the unaccusative-vs.-unergative divide. We then develop our account of the Italo-Romance variation, identifying the semantic parameters of subject agreement (Sections 5 and 6). Some conclusive remarks follow (Section 7).

\section{A typology of $\mathrm{V}-\mathrm{S}$ agreement in Italo-Romance}

\subsection{Preliminaries}

Before we delve into the details of $\mathrm{V}-\mathrm{S}$ agreement in Italo-Romance, we ought to clarify three issues. Firstly, following a well-established tradition (Rizzi 1986; Brandi and Cordin 1989; Benincà 1994a; Poletto 1993, 2000, among others), we consider personal subject clitics to be extended exponents of finite (person and number) agreement. This assumption is not uncontroversial. The distribution of subject clitics differs from that of inflectional agreement exponents (Renzi and Vanelli 1983; Vanelli 1997), and there is no systematic relation between gaps or syncretism, in the one paradigm, and unambiguous agreement, in the other. In some dialects, subject clitics are obligatory for all persons in interrogative clauses, where they invert with the verb, though not in affirmative clauses, where they precede the verb. These facts have led some to challenge the idea that subject clitics are extended agreement exponents (see, among others, Cardinaletti and Repetti 2010).

Relevant to our current discussion is the behavior of subject clitics in the Gallo-Italian dialects under examination. ${ }^{6}$ The fact that these subject clitics can co-occur with a co-

\footnotetext{
${ }^{6}$ The survey points were Scanzorosciate, Grosio, Milan, and Limbiate, in Lombardy; Turin, Oglianico, Asti, and Fontanelle di Boves, in Piedmont; Cairo Montenotte in Liguria. The data were gathered in 14 questionnaire-assisted interviews. The questionnaire consisted of 70 entries, divided into two main parts, one in the local dialect and the other one in standard Italian. The questions in the first part required the selection of one or more options from a set of alternatives, which were given within a context. The second part included
} 
referring subject pronoun or noun phrase within the same agreement domain (cf. 4a), differentiates them from topic pronouns, which are co-referent with detached or understood topical noun phrases. As is shown by the topic object pronoun $l$ ' in (4b), these pronouns cannot co-occur with their co-referent noun within the same agreement domain, here the clause. If they do, they incur in illicit clitic doubling. ${ }^{7}$

\section{(4) Grosio, Lombardy}

a. I nos ràis $i$ é partì.

the our children SCL.3PL be.3 left

'Our children have left.'
b. Tantisima gent $i$
(*l') $a$
vedù quel cinema.
many.SUPERL people SCL.3PL OCL have.3 seen that film
'Many people have seen that film.'

We should also note that while we found cases in which finite agreement is solely spelled out on the verb or on the subject clitic, due to syncretism or gaps in the subject-clitic

sentences for translation from Italian into the dialect. The context of each entry did not include S or V. Thus, allowance being made for a small number of inverse locatives (Cruschina 2012), the questionnaire entries represented all-new or sentence-focus utterances in the sense of Lambrecht (1994: 233-235). Although the majority of the questionnaire entries were in the perfect, the results were crosschecked with examples in the present tense, which were not questionnaire entries. The questionnaire was divided into four sections, which tested the following variables.

(i) The status of $\mathrm{V}$ as a copula or a semantically contentful verb.

(ii) The Aktionsart or lexical aspect of $\mathrm{V}$.

(iii) The entailment of a goal in the eventuality described by $\mathrm{V}$ or the lack thereof.

(iv) The specificity of S.

Sections I.1 and II.1 of the questionnaire tested variable (ii), factoring out variable (iv). In particular, these sections consisted of multiple entries per each Aktionsart type, with each verb figuring twice, once being followed by a definite S and the other by an indefinite S. Section I.2 tested variable (iii), as it included the GOAL-entailing and non GOAL-entailing verbs of inherently directed motion identified in Tortora (1997). Sections I.3 and II.3 tested variable (i). In particular, the latter section solely exhibited copular VS structures, while the former listed entries with a range of verbs which were to various degrees informationally light in the given context, in the sense of Levin and Rappaport Hovav (1995: 220-260). These are verbs conveying information that can be derived from the context and verbs that do not add substantially to the information conveyed by the post-verbal noun phrase. In some cases, these are verbs that impose strict selectional restrictions on their core argument, so that verb and argument are to some extent predictable from each other. Finally, Section II.2 tested variable (iv), i.e., definiteness in the sense of specificity (Enç 1991), insofar as its entries exhibited post-verbal pronouns. By way of example, we provide here the literal English translation of a questionnaire entry:

[You hear the door bell, you look out of the window, and you say: “...”]

a) Have knocked some people.

b) Has knocked some people.

The interviewees were adult native speakers of the dialect under scrutiny, who resided in the survey point, and were also fluent in Italian. Whenever possible, the interview was conducted by a local helper, under the supervision of the investigator. The helper was a native speaker of the dialect being examined. The results were analysed with the aid of spreadsheets.

${ }^{7}$ Clitic doubling is the co-occurrence of the clitic with the co-referent constituent within the same clause. It should not be confused with clitic resumption, which is instead characterized by the clause-external occurrence of the constituent which the clitic is coreferent with. Clitic doubling is found to varying extents in Spanish and Romanian, while it is generally considered to be absent in other Romance languages, with some exceptions, which we need not discuss here (see, e.g., Benincà 1988; 2001). 
paradigm or the verbal inflection, we did not find any evidence of unambiguously agreeing verb forms combining with unambiguously non-agreeing subject clitics, or vice versa, unambiguously non-agreeing verb forms combining with unambiguously agreeing subject clitics. This suggests that subject clitics spell out agreement in the same domains as the inflection does, whether overtly or covertly.

Secondly, we should explain why we confine our analysis to agreement on the finite form of the verb, that is, the form which spells out person and number agreement features in SV order. This type of agreement is shown here with Italian examples.

(5) Italian
a. I miei amici / Loro arriveranno alle 8 . the my friend.MPL they arrive.FUT.3PL at.the 8 'My friends / They will arrive at 8pm.'
b. I miei amici / Loro sono arrivati alle 8 . the my friend.MPL they be.3PL arrived.MPL at.the 8 'My friends / They have arrived at 8pm.'

In (5a), the verb arriveranno 'will arrive' agrees in person and number with the preceding noun phrase or third person plural pronoun. The same holds true of the perfect auxiliary sono 'are' in (5b). In the latter example, one also finds another type of subject agreement. Specifically, the participle of the perfect exhibits gender and number agreement with the subject. This type of agreement, also called nonfinite, will not be the focus of our analysis because its distribution is restricted to particular verb classes. For example, in Italian, it is solely found on the past participle of intransitive state-based predicates, whereas in other dialects the constraints on past-participle agreement are more fine-grained. In addition, some dialects of the extreme South of Italy have lost the agreement morphology on the participle of the perfect altogether (Loporcaro 1998: 161-170), whereas some of the dialects cited in this paper do not inflect arhizotonic participles for both numbers and both genders. Thus, Milanese rivà 'arrived' only inflects overtly for feminine singular, thus alternating with rivada 'arrived.FSG'. Although nonfinite agreement will be outside the scope of our analysis, in due course we will point out that the limited evidence available suggests that nonfinite $\mathrm{V}-$ $\mathrm{S}$ agreement systematically co-patterns with finite $\mathrm{V}-\mathrm{S}$ agreement in the dialects of our sample.

Thirdly, we assume that there is no $\mathrm{V}-\mathrm{S}$ agreement in person in the structures that patently lack V-S agreement in number. In accordance with Tortora's (1997) findings, these are never first and second person structures (see Section 5.5). An example was provided in (2) and is repeated here for convenience.

(6) Milan, Lombardy

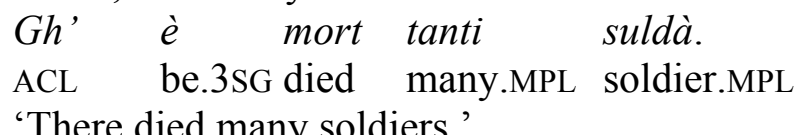

At first, one seems to be faced with conflicting evidence. In some dialects, the relevant VS structures lack the personal subject clitic that figures in their SV counterparts. The evidence in (6) is not cogent, since Milanese does not have a third-person-plural subject clitic. However, other dialects do have an agreeing third-person plural subject clitic (see $i$ in 7a), which is absent from the VS structures under discussion here (cf. 7b). (Incidentally, in (7a), agreement is only marked on the proclitic hosted by the auxiliary verb, since the third person singular and plural of 'be' are syncretic in this dialect.) 
(7) Scanzorosciate, Lombardy

a. $I \quad \grave{e}$ riàde $i$ tò sorèle / riàč di pachèč. SCL.3PL be.3 arrived.FPL the your sister.FPL arrived.MPL of parcel.MPL 'There arrived your sisters / some parcels.'

b. Gh' è riàt $i$ tò sorèle / di pachèč.

ACL be.3 arrived the your sister.FPL some parcel.MPL

'There arrived your sisters / some parcels.'

The lack of the personal subject clitic in (7b) suggests that there is no agreement for the feature person.

In the dialect of Cairo Montenotte, the agreeing personal subject clitic alternates with an invariant subject clitic, $u$, which also occurs in meteorological and other impersonal expressions. In (8a) we exemplify the agreeing subject clitic, while in $(8 b-d)$ we illustrate the invariant one (examples $8 b-d$ are drawn from Parry 2005: 170, 214).

(8) Cairo Montenotte, Liguria

a. I sun morti tanci surdoi.

SCL.3PL be.3PL died.MPL many.MPL soldier.MPL

'There died many soldiers.'

b. $U$ i èra ' $r$ dóne chi $i$ levòvu $i$ piul. ESCL ACL be.PST.3SG the women.FPL REL IOCL SCL.3PL remove.PST.3PL the stem 'There were the women who took the stem off.'

c. $U$ fiòca.

ESCL snow.3SG

'It snows.'

d. U mseugna.

ESCL need.3SG

'It is necessary.'

The third person plural subject clitic is $i$, as can be seen in (8a) and in the pseudo-relative clause following the main clause in (8b). Therefore, in the main clause of this example, the clitic $u$ is unequivocally expletive and does not agree with the post-copular noun phrase ' $r$ dóne 'the women'. Assuming as we do that person subject clitics are extended agreement exponents, the presence of an expletive clitic in VS structures like (8b) is indicative of the lack of agreement for any feature.

V-S constructions overtly lacking number agreement may exhibit a special copula. Thus, in Fontanelle di Boves (Piedmont), number agreement is marked on the copula 'be' (cf. 9a) and lack thereof on 'have' (cf. 9b).

(9) Fontanelle di Boves, Piedmont

a. Maria l' è nen da sula: $i$ sun mi.

Mary SCL be.3SG NEG byalone SCL.1SG be.1SG I

'Mary is not alone: there is me.'

b. Posuma nen separase: j a chii ciöt.

can.1PL NEG separate.REFL ACL have.3SG those MPL little MPL

'We cannot divorce: there are the children.'

As noted by a reviewer, (9a) and (9b) differ insofar as the former is in the first person, while the latter is in the third person. Indeed, in the copular constructions of this dialect, $\mathrm{V}-\mathrm{S}$ 
agreement is obligatory in first and second person, and ruled out in third person. With contentful verbs that require the perfect auxiliary 'be' (cf. 10a), however, agreement is optional in third person. Importantly, the lack of agreement is overtly marked on the perfect auxiliary 'have' (cf. 10b) and not on default 'be'.

(10) Fontanelle di Boves, Piedmont
a. Sun arivé 'd pacàt.
be.3PL arrived.MPL some parcel.MPL
b. $J$ a arivà ëd pacàt
ACL have.3SG arrived some parcel.MPL

'There arrived some parcels.'

We thus take Fontanellese $a$ 'has' to be an invariant allomorph of the copula and of the perfect auxiliary, which lacks agreement features altogether.

Admittedly, there are dialects where an unambiguous third-person singular clitic figures in constructions that lack V-S agreement in number. This is the case with the dialect of Grosio, where $(a) l$ is a third person singular clitic (cf. 11a), contrasting with $i$ in the third plural. Structures like $(11 \mathrm{~b}-\mathrm{c})$ could thus be claimed to exhibit person agreement of V with $\mathrm{S}$ (Manzini and Savoia 2005), although we note that the auxiliary in (11c) is invariant 'have', which clearly suggests that finite agreement is missing altogether.

(11) Grosio, Lombardy
a. Maria l' é migade per lé.
Mary SCL.3SG be.3 NEG of by her
'Mary is not alone.'
b. Su inti spazatečal gh'é mubilia vĕga. upstairs in the loft SCL.3SG ACL be.3 furniture.SG old.SG 'Upstairs in the loft there is some old furniture.'
c. Intan che l gh' eva la festa....
while that SCL.3SG ACL have.3SG.PST the party.SG
'During the party...' (Lit. While there was the party...)

There are, however, theoretical reasons to reject the hypothesis of the mismatch between $\mathrm{V}-\mathrm{S}$ agreement in third person and in number. In particular, if we postulate that the verb agrees with the post-verbal noun phrase in person in structures like (11b-c), we also have to assume V-S agreement in number, given that the post-verbal noun phrase is singular in these examples. This assumption leaves unexplained the patent lack of number agreement in VS constructions with a plural source.

(12) Grosio, Lombardy
L' é mort tanti
suldà.
SCL.3SG be.3 died many.MPL soldier.MPL
'There died many soldiers.'

By virtue of its nonpersonal (Benveniste 1966: 230-231) or nondeictic (Benincà 2007: 42) properties, that is, its failure of identification in discourse by means of the sole verbal inflection, the third person lends itself to the function of default, nonagreeing, morphology, i.e., overt inflection on targets that do not agree with a source. Throughout our analysis, we thus assume that the third-person singular morphology can be default, in which case it fails to spell out both person and number agreement in the dialects under scrutiny. 


\subsection{The three patterns}

We now describe in full the three patterns uncovered in our investigation. Most of the discussion deals with intransitive sentence-focus constructions (Lambrecht's 1994: 233235), which do not presuppose V or S (cf. 13a). We also take into consideration two types of there-sentence: existential there-sentences (cf. 13b) and inverse locatives (cf. 13c), this second copular structure representing argument focus (Cruschina 2012, 2015 and, for argument focus, Lambrecht 1994: 228-233). ${ }^{8}$ Finally, we discuss transitive constructions that are felicitous in a discourse context that presupposes $\mathrm{O}$, but not $\mathrm{V}$ or $\mathrm{S}$ (cf. 13d). In all the structures under examination, $\mathrm{S}$ is introduced as nonpresupposed information.

(13) a. There died many soldiers (yesterday, in the conflict).

b. ('What is there to light a bonfire with?') 'There is some old furniture.'

c. ('Who is at home?') 'The boys are (at home).'

d. (That film,) all my friends saw it.'

We begin with pattern (i), which is characterized by generalized person and number agreement of V with $\mathrm{S}$ in VS constructions. This agreement pattern is unchanged from Latin (though see Wehr 1984, 1995 for some deviations from it in Vulgar Latin), and is found in modern standard Italian, Friulian (Benincà 1994b: 117-118), as well as a great deal of central, southern and extreme southern dialects of Italy. The examples below are in standard Italian: in (14a) we illustrate V-S agreement in a transitive construction, whereas in the remaining sentences, we show generalized agreement in intransitive constructions with predicates of different Aktionsart types: an activity (cf. 14b), a state (cf. 14c), an achievement (cf. 14d), and an accomplishment (cf. 14e). ${ }^{9}$

(14) Italian
a. Quel film, l' hanno visto tutti $i$ miei amicil tante persone. that film OCL have.3PL seen all the my friend.MPL many person.FPL 'That film, all my friends / many people have seen it.'
b. Hanno chiamato $i$ tuoi genitori / tanti malati. have.3PL called the your parent.MPL many patient.MPL 'Your parents / many patients called.'

\footnotetext{
${ }^{8}$ Inverse locatives are copular constructions with a topical locative predicate and a focal post-copular argument. The locative predicate is either omitted or separated from the rest of the clause by an intonational break. The same predicate can be resumed clause-internally by a locative pro-clitic, which, in the dialects under investigation, is homophonous with the locative clitic exhibited by existentials.

(i) Italian
A. Chi c' è a casa?
who ACL be.3SG at home
'Who is at home?'
B. Ci sono $i$ ragazzi (a casa). ACL be.3PL the boys at home 'The boys are there (at home).'

${ }^{9}$ The Aktionsart of predicates is established on the basis of standard tests, for which we refer to Dowty (1979) and Van Valin (2005: 32-42). A discussion of the principal Aktionsart types and their semantic representation will be provided in Section 3. Observe in passing that nonfinite agreement on the participle of the perfect follows the same pattern as finite agreement in $(14 \mathrm{c}-\mathrm{e})$.
} 
c. Ieri sono stati male $i$ miei bambini / tanti bambini. yesterday be.3PL been.MPL unwell the my children.MPL many children.MPL 'Yesterday my children / many children were unwell.'

d. Sono arrivate le tue sorelle/ arrivati dei pacchi. be.3PL arrived.FPL the your sister.FPL arrived.MPL some parcel.MPL 'There arrived your sisters / some parcels.'

e. Sono scesi $i$ signori del piano di sopra be.3PL come.down.MPL the people.MPL of.the floor of upstairs dei signori del paese di sopra. some people.MPL of.the village of above 'There came down the people from upstairs / some people from the upper village.'

In accordance with the definiteness hierarchy that is known to underlie verb agreement (Givòn 1976: 152; Lehmann 2014 [1982]: 50), the same pattern of generalized $\mathrm{V}-\mathrm{S}$ agreement is found in constructions where $\mathrm{S}$ is a personal pronoun.

(15) Italian

a. Alle due siete arrivati voi. at.the two be.2PL arrived.MPL you.PL 'At 2 o'clock you arrived.'

b. Poi sono venuti loro. then be.3PL come.MPL they 'Then they arrived.'

b. Maria non è sola: ci sono io. Mary NEGbe.3SG alone ACL be.1SG I 'Mary is not alone: there is me.'

Generalized V-S agreement is also found in copular there-sentences. ${ }^{10}$ Those in $(16 \mathrm{a}-\mathrm{b})$ are existential there-sentences, whereas (16c) is an inverse locative (see note 8 ). In the remainder of the paper, we indicate argument focus with small caps.

(16) Italian

a. Non possiamo divorziare: ci sono $i$ bambini.

NEG can divorce ACL be.3PL the children.MPL

'We cannot divorce: there are the children.'

b. Cosa c' è da bruciare? Ci sono dei mobili vecchi. what ACL be.3SG to burn ACL be.3PL some furniture.MPL old.MPL 'What is there to be burned? There is some old furniture.'

c. Ci sono I RAGAZZI (a casa). ACL be.3PL the boy.MPL athome

'The boys are there (at home).'

In sum, pattern (i) is characterized by systematic $\mathrm{V}-\mathrm{S}$ agreement regardless of the semantic class of the agreeing verb and of the pragmatico-semantic properties of the postverbal controller.

Pattern (ii) is well attested in the Gallo-Italian dialects of Piedmont, Lombardy and Liguria. We found it in Cairo Montenotte, which is a dialect of transition between Ligurian

\footnotetext{
${ }^{10}$ The sole deviation from generalized finite agreement optionally emerges in existential there-sentences with INDE-cliticization. We return to this in Section 5.4.
} 
and Piedmontese (Parry 2005), as well as in Turin, Oglianico, Asti, Fontanelle di Boves (Piedmont) and Milan, Scanzorosciate and Limbiate (Lombardy). Again, V-S agreement is generalized when the source is a personal pronoun. ${ }^{11}$

(17) Cairo Montenotte, Liguria
a. Pö $i$ sei rivòi vui otri.
then SCL.2PL be.2PL arrived.MPL you.PL other.PL
'Then you arrived.'

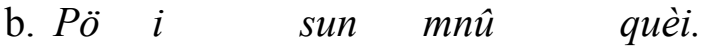
then SCL.3PL be.3PL come.MPL they
'Then they arrived.'
c. Maria a l' è nèn sula: $a$ sun mi.
Mary SCL.3SG SCL be.3SG NEG alone SCL.1SG ACL be.1SG I
'Mary is not alone: there is me.'

(18) Milan, Lombardy
a. Pö si rivà vui alter.
thenbe.2PL arrived you.PL other
'Then you arrived.'
b. Pö in rivà lur.
thenbe.3PL arrived they
'Then they arrived.' the Mary SCL be.3SG NEG in of by her ACL be.1SG I
'Mary is not alone: there's me.'
c. La Maria l' è no in de per lé: ghe sun mi.

(19) Fontanelle di Boves, Piedmont

a. Curaseve arivé vate.

then be.2PL arrived.PL you.PL

'Then you arrived.'
b. Maria l' è nen da sula: $i$ sun mi.
Mary SCL be.3SG NEG by alone ACL be.1SG I

'Mary is not alone: there is me.'

As for VS constructions with a noun-phrase, in the dialect of Cairo Montenotte those with a copula lack V-S agreement, see (20a), (20b) and (20c), while those with a contentful verb do not, see (21a) to (20e). ${ }^{12}$ We call this sub-pattern (iia).

\footnotetext{
${ }^{11}$ In two of the dialects investigated, Asti and Fontanelle di Boves, third person pronouns turned out to behave as noun phrases. This is why we do not provide an example with a third person pronoun in (19). For a discussion of this point see Section 5.5.

${ }^{12}$ Parry (2005: 212-213) provides evidence of lack of V-S agreement with contentful verbs in Cairese, and this also emerged sporadically in our more recent investigation.
}

(i) Cairo Montenotte, Liguria
Vorda: u $i$
look ESCL ACL be.3SG come.in two little.bird.MPL
'Look! There entered two little birds.' 
(20) Cairo Montenotte, Liguria

a. As poruma nèn divurzié perchè $u$ i $\quad$ è $i$ fiöi.

REFL can.1PL NEG divorce because ESCL ACL be.3SG the children.MPL 'We cannot divorce because there are the children.'

b. Cós $u \quad i \quad$ è da brižè?? $U$ i è di mobili vègi. what ESCL ACL be.3SG to burn ESCL ACL be.3SG some furniture.MPL old.MPL 'What is there to make a bonfire with? There is some old furniture.'

c. $U \quad i \quad \grave{e}$ I MATOTI (a ca).

ESCL ACL be.3SG the boy.MPL athome

'The boys are there (at home).'

(21) Cairo Montenotte, Liguria

a. Cul cine, $i \quad l$ an vist-le tûti $i$ mei amiži/ tante persune. that film SCL.3PL OCL have.3PL seen-OCL all the my friend.MPL many people.FPL 'That film, all my friends / many people have seen it.

b. I an ciamò $i$ toi genituri / tanci clienti. SCL.3PL have.3PL called the your parent.MPL many customer.MPL 'Your parents / many customers called.'

c. I sun restòi $i$ toi studenti / tanci studenti. SCL.3PL be.3PL remained.MPL the your student.MPL manystudent.MPL 'Your students / Many students stayed behind.'

d. I sun rivòie er tò surèle / rivòi di pèchi. SCL.3PL be.3PL arrived.FPL the your sister.FPL arrived.MPL some parcel.MPL 'There arrived your sisters / some parcels.'

e. I sun mnûu inter pais $i$ toi noni / SCL.3PL be.3PL come.MPL in the village the your grandparent.MPL imnûe der persune. come.FPL of.the people.FPL

'There came (into the village) your grandparents / some people.'

In $(21 \mathrm{a}-\mathrm{e})$, both the subject clitic and the inflection on the auxiliary of the perfect exhibit the third-person plural features of the post-verbal noun phrase ( $i$ an 'SCL.3PL have.3PL' or $i$ sun 'SCL.3PL be.3PL'). ${ }^{13}$

A second sub-pattern of (ii), which we call (iib), was found in the remaining Gallo-Italian dialects listed above. Again, the copula does not exhibit V-S agreement.

(22) Milan, Lombardy

a. Podum no divides: $\quad$ a gh' è $i$ fiö. can.1PL NEG separate.REFL ESCL ACL be.3SG the children.MPL 'We cannot divorce: there are the children.'

b. Se gh' è per fà la legna? Gh'è di mobil več. what ACL be.3SG for do the wood ACL be.3SG of furniture.PLold.PL 'What's there to make wood to burn?' 'There is some old furniture.'

c. Gh' $\grave{e} \quad I \quad F I \ddot{O} \quad$ (in $c \grave{a}$ ).

ACL be.3SG the boy.MPL in home

'The boys are there (at home).'

\footnotetext{
${ }^{13}$ Nonfinite agreement on the past participle is also consistently found, subject to the independent verb class restrictions mentioned in Section 2.1, see (21b) vs. (21c) to (21e).
} 
(23) Fontanelle di Boves, Piedmont

a. Posuma nen separase: j' a chii ciöti.

Can.1PL NEG separate.REFL ACL have.3SG those.MPL little.MPL

'We cannot divorce: there are the children.'

b. Co j' a per fò ëd bosch? J' a 'd mòbil vej. what ACL have.3SG for do some fire ACL have.3SG some furniture.PL old.PL 'What's there to make a fire?' 'There is some old furniture.'

c. $J \quad a \quad I \quad$ MATAT $\left(\begin{array}{lll}a & c a\end{array}\right)$.

ACL have.3SG the.MPL boys at home

'The boys are there (at home).'

$\mathrm{V}-\mathrm{S}$ agreement is, instead, obligatory in transitive constructions, where the object is obligatorily topicalized and detached syntactically, and resumed clause-internally by an object clitic, see (24a) and (25a). V-S agreement is also obligatory with activity predicates, see $(24 b)$ and $(25 b)$.

(24) Milan, Lombardy

a. Chelfilm li, l' an vist tüti $i$ meamis / tanti person. that film DEM OCL have.3PL seen all the my friend.MPL many people.FPL 'That film, all my friends / many people have seen it.'

b. An ciamà $i$ tò gent / tanti malà. have.3PL called the.PL your people many.MPL patients 'Your parents / Many patients have called.'

(25) Fontanelle di Boves, Piedmont

a. Che cine li, l' an vist tüti $i$ me amis / tanti italiegn. that film DEM OCL have.3PL seen all the my friend.MPL many.MPL Italians 'That film, all my friends / many Italians have seen it.'

b. $L$ ' an ciamà $i$ tò / tanti malavi.

SCL.3 have.3PL called the yours manypatient.MPL

'Your parents / Many patients have called.'

V-S agreement is optional with states, see (26a), (26b), (27a), (27b), achievements, see (28a), (28b, (29a), (29b), and accomplishments, see (30a), (30b), (31a), (31b), and the lack of $\mathrm{V}-\mathrm{S}$ agreement systematically correlates with the surfacing of an etymologically locative clitic, which is the same as was found in copular there-sentences (Milanese ghe, and Fontanellese $j<$ Latin HIC/IBI/ILLIC/ILLI, Benincà 2007: 34). ${ }^{14}$

(26) Milan, Lombardy

a. Ier gh' ̀̀ astà mal $i$ me fiö / tanti fiö.

yesterday ACL be.3SG been unwell the my children.MPL many children.MPL

b. Ier in astà mal $i$ me fiö / tanti fiö.

yesterday be.3PL been unwell the my children.MPL many children.MPL

'Yesterday my children / many children were unwell.'

(27) Fontanelle di Boves, Piedmont

\footnotetext{
${ }^{14}$ Again, in (29b), (30b) and (31b) we have evidence suggesting that nonfinite agreement co-patterns with finite agreement in the verbs or verb classes that independently require it.
} 

a. J a està $i$ tò esculè /d'esculè. ACL have.3SG stayed the your pupil.PL / some pupil.PL
b. ??Sun estò $i$ tò esculè / d' esculè. be.3pl stayed.PL the your pupil.PL some pupil.PL 'Your pupils / some pupils stayed behind.'

(28) Milan, Lombardy
a. Gh' è rivà $i$ tò surèi / di pac. ACL be.3SG arrived the your sister.FPL some parcel.MPL
b. In rivà $i$ tò surèi / di pac. be.3PL arrived the your sister.FPL some parcel.MPL 'There arrived yours sisters / some parcels.'

(29) Fontanelle di Boves, Piedmont
a. $J^{\prime} a$ arivà ëd LCL have.3SG arrived some parcel.MPL the your sister.FPL
b. Sun arivé 'd pacàt/ arivò $i$ töe söre. be.3PL arrived.PL some parcel.MPL arrived.PL the your sister.FPL 'There arrived some parcels / your sisters.'

(30) Milan, Lombardy
a. Gh' è vegnùgió $i$ sciur del pian de sura /
ACL be.3SG come down the.MPL people of.the floor of upstairs
di gent.PLdel paes de sura.
some people of.the village of above
b. In vegni gió $i$ sciur del pian desura / be.3PL come.PL down the.MPL people of.the floor of upstairs di gent del paes de sura.

some.PL people of.the village of above

'There came down the people from upstairs / some people from the upper village.'

(31) Fontanelle di Boves, Piedmont
a. $J$ ' calà ëd giant $d a$ u paìs de tsure / $i$ tò nonu. LCL have.3SG come.down some people from the village of above the your gr.PL 'There came down some people from the upper village / your grandparents.'
b. Sun calé 'd perzune. be.3PL come.down.PLsome people.PL 'There came down some people.'

In-depth examination of state-based intransitives uncovered other results that are worthy of mention. In particular, differently from contingent or resultant states (cf. 32a), inherent states (property concepts, see Dixon 1980: 52; Schwartz 1993; see Section 3) regularly exhibited agreement (cf. 32b).

(32) Milan, Lombardy
a. Stamatina in / gh' è astà mal $i$ me fiö. this morning be.3PL ACL be.3SG been unwell the my children.MPL 'This morning my children were unwell.' 
b. In quest'ann in / *gh' ̀̀ astà intelligent /

in this year be.3PL ACL be3SG been intelligent

alt/biund tüti $i$ me scular.

tall / blond all the my pupils.MPL

'This year all my pupils were intelligent / tall / blond.'

In Fontanellese VS constructions with state predicates are odd, and were only deemed to be acceptable when V-S agreement is missing (see, by way of example, (27a)-(27b). VS constructions with inherent states were deeded to be ungrammatical.

In addition, fewer than $10 \%$ of the responses obtained in scene descriptions with change of state or change of location verbs exhibited V-S agreement. ${ }^{15}$

(33) Milan, Lombardy

a. Varda:gh' ̀̀ vegnù gió tanti pom.

look ACL be.3SG fallen downmany.PL apple

'Look! There fell many apples on the ground.'

b. Varda:gh' ’̀ vegnù denter dü uselit.

look ACL be.3SG come inside two bird.MPL

'Look! There entered two little birds.'

c. Varda:gh' ̀̀ vegnù föra di barc.

look ACL be.3SG come out some.PL boats

'Look! There appeared some sailing boats in the distance.'

(34) Fontanelle di Boves, Piedmont

a. Bèica: j a calà tante pume.

look ACL have.3SG fallen manyapple.FPL

'Look! There fell many apples on the ground.'

b. Bèica: $j$ a entrà due pasarot.

look ACL have.3SG come.in two birds

'Look! There entered two little birds.'

c. Bèica: $j$ a surtì ëd barche.

look ACL have.3SG appeared some boat.FPL

'Look! There appeared some sailing boats in the distance.'

While the sentences in $(33 a-c)$ and $(34 a-c)$ describe the result of events of 'falling', 'appearing' and 'coming (in)', it could be argued that the verb is redundant, in that it cannot contribute any information that cannot be derived from the context (see Levin and Rappaport Hovav 1995: 220-260's notion of information lightness). The post-verbal noun phrase, in turn, is the affected argument of a change of location or change of state predicate.

To recapitulate, a distinction can be drawn between two sub-patterns of pattern (ii). In the one sub-pattern, which we called (iia), V-S agreement is the norm when V is a contentful

\footnotetext{
${ }^{15}$ These scene descriptions were found in Section I.3 of the questionnaire (see note 6), where the informant was given two dialect alternatives to describe a scene to a partner or friend. The literal translation of one of these questionnaire entries is provided here.
}

[Imagine that you arrive home with your wife/husband. Describe what you see, as you are coming in]

a) Look: are come in two little birds.

b) Look: there has come in two little birds. 
verb. In the other, which we called (iib), V-S agreement appears at first to be sensitive to the contrast between state-based and non state-based predicates. This contrast is reminiscent of the unaccusative-unergative split (Perlmutter 1978; Burzio 1986; Van Valin 1990, among others, see Section 4). However, we uncovered a number of tendencies with contingent and inherent states and, on the other hand, change-of state or change-of-location predicates, which suggest that a more subtle principle underlies the relevant agreement alternations. Lastly, in all the dialects with pattern (ii), an etymologically locative clitic occurs systematically in concomitance with the failure of $\mathrm{V}$ to agree with the post-verbal $\mathrm{S}$.

Turning now to pattern (iii), no difference from the other patterns is found in copular and verbal constructions where the source is a personal pronoun. (Agreement is only spelled out on the subject clitic $i$ in $35 \mathrm{~b}$, since the third person singular and plural of 'be' is syncretic in this dialect).

(35) Grosio, Lombardy
a. Dopu sef rivä valtri. then be.2PL arrived you.PL 'Then you (pl) arrived.'
b. Dopu $i$ é rivä lor. then SCL.3PL be.3 arrived they 'Then they arrived.'
c. Maria l' é miga de perlé:ghe son mi. Mary SCL.3SG be.3SG NEG of by her ACL be.1SG I 'Mary is not alone: there is me.'

When the source is a noun phrase, instead, V-S agreement is ruled out in copular theresentences, see (36a), (36b), (36c), and with state-based predicates, see (37a) to (37d).

(36) Grosio, Lombardy

a. An po migatös fo: al gh’é $i$ ràis.

SCL.1PL can NEG take.REFL out SCL.3SG ACL be.3 the children.MPL

'We cannot divorce: there are the children.'
b. Al gh'é mubilia vĕga.
SCL.3SG ACL be.3 furniture old
'Upstairs in the loft there is some old furniture.'
c. Al gh'é I RÀIS (a ché).
SCL.3SG ACL be.3 the children.MPL at home
'The boys are there (at home).'

(37) Grosio, Lombardy

a. $L$ ' è restä $i$ te student / un quai student. SCL.3SG be.3 stayed the.PL your students a some students 'There remained your students / some students.'

b. $L$ ' è rivä $i$ toa sureli / di pac.

SCL.3SG be.3 arrived the your sister.FPL some parcel.MPL

'There arrived your sisters / some parcels.'

c. $L^{\prime} \quad \dot{e}$ mort tant suldà.

SCL.3SG be.3 died many soldier.MPL

'There died many soldiers.'

d. L' é vignigió vergun del paes de sora / SCL.3SG be.3 come down some of.the village of upstairs 
$i \quad$ te läf.

the.MPL your grandparents.

'There came down some people from the upper village / your grandparents.'

$\mathrm{V}-\mathrm{S}$ agreement is allowed with intransitive activities, see (38a) and (38b), and required in transitive predications with a topicalized object and a post-verbal subject (cf. 39). More precisely, with non state-based intransitives, subject agreement figured in the responses of speakers aged 70 and above, while younger speakers normally ruled it out. (Although the third person singular and plural of 'have' is syncretic, agreement is unmistakeably spelled out on the subject clitic $i$ in 38a and 39).

(38) Grosio, Lombardy

a. I a ciamä al te pa e la toa mama/tančmalä.

SCL.3PL have.3 called the your Dad and the your Mum many.PL patients

'Your Mum and Dad / Many patients called.'

b. L' a ciamä al te pa e la toa mama/tančmalä.

SCL.3SG have. 3 called the your Dad and the your Mum many.PL patients

'Your Mum and Dad / many patients called.'

(39) Grosio, Lombardy

Quel cinema, $i \quad l$, a vedu tantisima gent.

that film SCL.3PL OCL have.3 seen many.SUPERL people.PL

'That film, many people have seen it.'

Observe that the absence of $\mathrm{V}-\mathrm{S}$ agreement does not correlate with the presence of an etymologically locative clitic in Grosino. This is only found in the copular constructions, regardless of agreement, see (35c) and (36a), (36b), (36c). In this sense, pattern (iii) differs from pattern (iib), where the appearance of an etymologically locative clitic consistently matches the absence of $\mathrm{V}-\mathrm{S}$ agreement in constructions with a contentful verb (compare the examples in 26 to 31 with those in $37 \mathrm{a}-\mathrm{d}$ ).

Therefore, pattern (iii) is comparable to patterns (iia-b) in exhibiting a split in $\mathrm{V}-\mathrm{S}$ agreement when $\mathrm{S}$ is a noun phrase. However, the cut-off point in $\mathrm{V}-\mathrm{S}$ agreement is not the same as in (iia-b). In (iii), transitives require $\mathrm{V}-\mathrm{S}$ agreement, intransitive activities can be said to allow it (though note the generational difference mentioned above) and state-based intransitives rule it out.

To conclude, whereas in pattern (i) subject agreement is fully grammaticalized, in patterns (iia-b) and (iii) it is sensitive to semantic constraints that emerge in VS order, where the agreement source is not presupposed and follows the target. Abstracting away from the case of personal pronouns, our findings can be represented schematically as in Table 1. In turn, the implicational scale in (40) emerges from this Table.

Table 1: Italo-Romance patterns of V-S agreement by verb type (excluding pro S)

\begin{tabular}{|l|c|c|c|c|}
\hline & Transitive V & $\begin{array}{l}- \text { state-b. } \\
\text { intransitive }\end{array}$ & $\begin{array}{l}\text { + state-b. } \\
\text { intransitive }\end{array}$ & $\begin{array}{l}\text { existential } \\
\text { copula }\end{array}$ \\
\hline (i) Italian & + & + & + & + \\
\hline (iia) Cairese (C. Montenotte) & + & + & + & - \\
\hline (iib) Milanese, Fontanellese & + & + & +- & - \\
\hline (iii) Grosino (Grosio) & + & +- & - & - \\
\hline
\end{tabular}


(40) V-S agreement: with transitives $>$ with non state-based intransitives $>$ with state-based intransitives $>$ in existential there-sentences.

According to the scale in (40), if existential there-sentences exhibit V-S agreement so do VS constructions with a contentful verb. If state-based intransitives exhibit V-S agreement, so do non state-based intransitives, and so on. Observe in passing that locative there-sentences can be subsumed under state-based intransitives for the purposes of the scale in (40). We return to this point in the next section.

\section{Predicate classification, macrorole assignment and subject agreement}

We now discuss state-based and non state-based predicates in more depth and we explain how predicate classification underlies the account of finite verb agreement that is proposed here.

In our framework, called Role and Reference Grammar (Van Valin and LaPolla 1997; Van Valin 2005), the semantic representation of clauses is based on the semantic representation or logical structure - of the predicators contained in them. The logical structure of a predicate depends on its Aktionsart and is built up incrementally, combining and enriching basic event templates to yield complex event templates. Drawing upon Vendler (1967), the framework distinguishes between the four Aktionsart types state, activity, achievement, and accomplishment. ${ }^{16}$ State and activity are the basic types, while the others derive from them. Both states and activities are [-telic] and [-punctual]. However, states describe static situations, whereas activities describe dynamic ones. The static or dynamic property of a predicate is tested in terms of its compatibility with the progressive aspect and with manner adverbs such as actively and energetically. Both of these properties solely characterize activities, although the incompatibility of states with the progressive aspect is language specific. Activities are represented as in $(41 \mathrm{a}-\mathrm{c})$. DO in $\left(41 \mathrm{a}^{\prime}\right)$ indicates lexically encoded agentivity.

(41) Activities
a. DO (x, [do' (x, [pred' (x)])])
b. do' $\left(\mathrm{x},\left[\operatorname{march}^{\prime}(\mathrm{x})\right]\right)$ 'march'
c. do' $\left(\mathrm{x},\left[\right.\right.$ draw' $\left.\left.^{\prime}(\mathrm{x},(\mathrm{y}))\right]\right)$ 'draw'

Within states, a distinction is drawn between property concepts, or inherent states, and contingent or result states (Dixon 1982: 50 and, in the framework adopted here, Schwartz 1993). Property concepts are underived states, such as red (cf. 42a), while result states are states that derive from change-of-state events whose name normally shares the same root as the name of the corresponding result state. An example of these is frozen (see frozen' in 42b). The logical structure proposed for contingent or stage-level states (Carlson 1977), which describe stages as opposed to properties of individuals, is the same as the logical structure of result states.

(42) States
a. be' $\left(x,\left[\right.\right.$ red' $\left.^{\prime}\right)$ 'red'
b. frozen' ( $\mathrm{x}$ ) 'frozen'

\footnotetext{
${ }^{16}$ To these, Van Valin (2005: 32) adds the nonVendlerian class of semelfactives (Smith 1997: 55-58), which we will not deal with here.
} 
Existential and locative there-sentences are also stative predications and require some discussion in this context. Existential there-sentences are context dependent (Francez 2007, 2010). As such, they do not predicate existence in an absolute or ontological sense, but rather they express propositions on existence or presence in an implicit, i.e., semantically unspecified, spatio-temporal domain. Thus, the statement in (43) is not a proposition on the existence of coffee in an absolute sense, but rather a proposition on its existence or presence in an understood and implicit domain.

(43) There is no coffee.

Similarly, (44), as a felicitous reply to the question 'What is there to light a bonfire with?', is a proposition on the existence or presence of old furniture in an implicit spatio-temporal domain, whose deixis is provided by the context of the utterance.

(44) Italian

Ci sono dei mobili vecchi.

ACL be.3PL some furniture.MPL old.MPL

'There is some old furniture.'

The implicit domain of existential there-sentences has been argued to be their sole argument in argument structure (Cruschina 2012; Bentley et al. 2015), the post-copular noun phrase predicating a property of the implicit argument (Cornilescu 2009; Francez 2007, 2010; Hazout 2004; Zamparelli 2000, etc. and, for a slightly different view, La Fauci and Loporcaro 1997). ${ }^{17}$ The logical structure of the existential there-sentence in (44) can thus be represented as in (44'), which follows Van Valin's (2005: 48-49) principles for the representation of copular constructions. ${ }^{18}$

$\left(44^{\prime}\right)$ be' $^{\prime}(\mathrm{x},[$ mobili vecchi])

\footnotetext{
17 The implicit domain can be modified and enriched by an overt adverb or locative phrase, the so-called coda, although this phrase is not required by the construction and hence will not be discussed here.

${ }^{18}$ As argued in Bentley (2015b), a distinction ought to be drawn in logical structure between existential theresentences with nonreferential and referential post-copular noun phrases. A prime example of the former type is that of existentials with a post-copular adjective (cf. i), while a prime example of the latter type is contextualized existentials with post-copular pronouns or definite noun phrases (cf. ii, Abbott 1992, 1993).
}

(i) San Tommaso, Calabria
A Torinu c' è togu.
at Turin ACL be.3SG nice.ADJ
'There is niceness in Turin'
be' $^{\prime}\left(\mathrm{x},\left[\right.\right.$ nice'$\left.\left.^{\prime}\right]\right)$
(ii) Per aiutarti ci sono io. (Italian)
to help.youACL be.1PL I
'To help you there is me'

In the logical structure in (i), the predicative position in brackets is filled by the post-copular adjective, which describes a property that is predicated of the implicit argument, see (42a) and (42b). This logical structure is identical to that of property concepts, exception being made for the lack of specification of the argument x. For simplicity, we disregard this type of existential construction here, although we should note that it provides evidence that the post-copular noun phrase or adjectival phrase of existential there-sentences is a predicate in semantics. 
$\mathbf{B e}^{\prime}$ does not represent the copula (Van Valin 2005: 48), but rather indicates that a predicative relation holds between the post-copular noun phrase and the implicit argument. The latter figures in logical structure as $\mathrm{x}$, since it is nonreferential and semantically unspecified, its deixis being understood from the discourse context. While being semantically unspecified, this argument can be spelled out phonologically by a nonreferential etymologically locative clitic (Cruschina 2012, 2015; Bentley 2015a; Ciconte 2015), such as Italian $c i$ (cf. 44), Cairese $i$, Milanese ghe, Fontanellese $j$, etc. ( $<$ Latin HIC/IBI/ILLIC/ILLI, Benincà 2007: 34).

(45) Cairo Montenotte, Liguria
a. $U \quad i \quad \grave{e} \quad d i$
ESCL ACL be.3SG some
mobili vegi.
b. Gh'
furniture.MPL old.MPL
ACL be.3SG some furniture.MPL old.MPL
c. $J \quad a \quad$ 'd mobil vej. (Fontanelle di Boves, Piedmont)
ACL have.3SG some furniture.MPL old.MPL
'There is some old furniture.'

In fact, the nonreferential locative clitic appears in the existential there-sentences of all the dialects under scrutiny, regardless of the agreement pattern they abide by. ${ }^{19}$ This is strong evidence for the claim that these sentences have an implicit argument in their logical structure.

Locative copular sentences, see (46a) and (46a'), have two specified expressions in logical structure, which are related by a locative predicative relation. Whereas in existentials it is the second expression that serves as the predicate, in locatives this role is taken by the expression in the first position (Van Valin 2005: 49). Locative copular sentences are thus state-based intransitive constructions with a nonverbal predicate. As for inverse locatives (cf. 46b), following Cruschina $(2012,2015)$ and Bentley and Cruschina (2016), we temporarily assume here that they are identical to noninverse locative copular sentences in logical structure, and that their special morpho-syntactic properties are entirely accounted for by their discourse properties, i.e., the topicality of the location and the focality of the argument (see note 8). This issue will be revisited in due course.

(46) Italian
a. I ragazzi sono a casa.
the boys be.3PL at home
'The boys are at home.'
a'. be-LOC' (casa, ragazzi)
b. $\mathrm{Ci}$ sono I RAGAZZI (a casa).
ACL be.3PL the boy.MPL at home
'The boys are there (at home).'

Moving on to achievements and accomplishments, these are [+telic] and denote the attainment of a result state. Since they include a result state, they are state-based types of predicate. Achievements differ from accomplishments in being [+punctual]. They thus lack the PROC operator, which is found in the logical structure of accomplishments and indicates their durative component. ${ }^{20}$

\footnotetext{
${ }^{19}$ See Bentley et al. (2015) for the Romance languages that have no locative clitic in there-sentences.

${ }^{20}$ INGR and PROC represent two decompositional operators that are part of word meaning, indicating change (INGR) and, respectively, duration (PROC) before change.
} 
(47) Achievements

a. INGR explode' (x) 'explode'

b. INGR be-at' (x) 'arrive'

(48) Accomplishments

a. PROC INGR frozen' ( $x$ ) 'freeze'

b. PROC INGR know' (x, y) 'learn'

There are also active accomplishments, which are built on the basis of the logical structures of an activity and an accomplishment. These predicates describe activities leading to a nonpunctual change of state, see (49a) and (49b).

(49) Active accomplishments

a. do' (x, [run' (x)]) \& PROC INGR be-LOC' (y, x) 'run to y'

b. do' (x, [draw' (x, y)]) \& PROC INGR created' (y) 'draw y'

There are standard tests to determine the Aktionsart of the predicate of a clause (Dowty 1979, Van Valin and LaPolla 1997: 91-102), although for brevity we will not discuss them here.

In logical structure, the argument positions are variables $(\mathrm{x}, \mathrm{y})$, which are filled by argument values in semantics-syntax or syntax-semantics linking (Van Valin 2005: 128182). The arguments that figure in the semantic representation of the predicate of the clause are called core arguments. Arguments and, more broadly, referential expressions, are represented in the language under investigation. The operators (e.g., PROC) and the constant, i.e., the idiosyncratic part of the meaning that identifies the given lexeme, distinguishing it from the others of the same lexical-semantic class (e.g. march'), are conventionally represented in English.

Two types of semantic relation are posited (Dowty 1991; Van Valin and LaPolla 1997: 82-138; Van Valin 2005: 53-67): thematic relations and generalized semantic roles or macroroles. For the purpose of semantics-syntax linking, thematic relations are defined in terms of the positions of core arguments in the logical structure of the predicate (Jackendoff 1976). Five such positions are relevant to the linking.

(50) Semantic positions which are relevant to the linking

$\begin{array}{lllll}\text { Arg of } & \text { 1st arg of } & \text { 1st arg of } & \text { 2nd arg of } & \text { arg of state } \\ \text { DO } & \text { do }^{\prime}(\mathrm{x}, \ldots) & \text { pred }^{\prime}(\mathrm{x}, \mathrm{y}) & \text { pred }^{\prime}(\mathrm{x}, \mathrm{y}) & \text { pred }^{(\mathrm{x})}\end{array}$

There are only two macroroles, actor and undergoer, and their relation to argument positions is captured by the Actor-Undergoer Hierarchy (Van Valin 2005: 61).

(51) The Actor - Undergoer Hierarchy and its mapping on to argument positions ACTOR

UNDERGOER

\begin{tabular}{|l|l|l|l|l|}
\hline Arg of DO & $\begin{array}{l}\text { 1st arg of } \\
\mathbf{d o}^{\prime}(\mathrm{x}, \ldots\end{array}$ & $\begin{array}{l}\text { 1st } \arg \text { of } \\
\text { pred }^{\prime}(\mathrm{x}, \mathrm{y})\end{array}$ & $\begin{array}{l}\text { 2nd } \arg \text { of } \\
\text { pred }^{\prime}(\mathrm{x}, \mathrm{y})\end{array}$ & $\begin{array}{l}\text { Arg of state pred } \\
(\mathrm{x})\end{array}$ \\
\hline
\end{tabular}

$\left[{ }^{\prime} \rightarrow '=\right.$ increasing markedness of realization of argument as macrorole $]$ 
Actor and undergoer are the two primary arguments of transitive predications, while either one of them can be the single argument of an intransitive predicate. The macrorole assignment principles are as follows.

(52) Default Macrorole Assignment Principles (Van Valin 2005: 63)

a. Number: the number of macroroles a verb takes is less than or equal to the number of arguments in its logical structure.

1. If a verb has two or more arguments in its logical structure, it will take two macroroles.

2. If a verb has one argument in its logical structure, it will take one macrorole.

b. Nature: for verbs which take one macrorole,

1. If a verb has an activity predicate in its logical structure, the macrorole is actor.

2. If a verb has no activity in its logical structure, the macrorole is undergoer.

Macrorole is a key construct in semantics-syntax, as well as syntax-semantics, linking (Van Valin and LaPolla 1997: 139-147; Van Valin 2005: 60-67), in that the macrorole assigned to a core argument determines its coding and behaviour in morphosyntax. The default choice for subjecthood diagnostics such as the control of finite verb agreement and co-reference or syntactic control phenomena is actor in accusative alignment and undergoer in ergative alignment. Thus, in accusative alignment, finite verb agreement is predicted to be determined by the rule in (53), where 'highest-ranking' means highest on the hierarchy of semantic positions shown above and repeated for convenience in (54). This is claimed to be a semantic hierarchy of subjecthood (Van Valin and LaPolla 1997: 175).

(53) Finite verb agreement (Van Valin 2005: 108)

The controller of finite verb agreement is the highest-ranking macrorole argument.

(54) $\operatorname{Arg}$ of DO $>1$ st $\arg$ of do $^{\prime}(\mathrm{x}, \ldots)>1$ st $\arg$ of pred $^{\prime}(\mathrm{x}, \mathrm{y})>2$ nd $\arg$ of pred' $(\mathrm{x}, \mathrm{y})>$ arg of state pred' (x).

The rule in (53) captures $\mathrm{S}-\mathrm{V}$ agreement in Italo-Romance and, more broadly, in accusative alignment. To give but one example, in active transitive constructions, the actor is chosen as controller of subject agreement, as illustrated by the Italian example below. In particular, in (55), the actor controller is the 1st argument of do $^{\prime}(\mathrm{x}, \ldots)$, whereas the undergoer is the only argument of a state pred' (x).

(55) Italian
a. Pietro ha scritto due libri.
Peter have.3SG written two books
'Peter has written two books.'
$a^{\prime}$. do' (Pietro, [write' (Piero)]) \& PROC INGR created' (libri)

In intransitive constructions, there is only one macrorole argument, which is trivially the highest one, and will control $\mathrm{S}-\mathrm{V}$ agreement regardless of whether it is an actor or an 
undergoer. ${ }^{21}$ Thus, S-V agreement neutralizes the difference between the two macroroles in a paradigmatic sense, in that the controller can be an actor or an undergoer. S-V agreement thus abides by a syntactic alignment principle, which, as we said, is the accusative one because actor, or the highest-ranking argument on the scale in (54), is the default choice of controller.

Turning now to V-S agreement, we claimed above that the scale in (56) (cf. 40) emerges from the cross-dialectal variation uncovered in our investigation.

(56) V-S agreement: with transitives $>$ with non state-based intransitives $>$ with state-based intransitives $>$ in existential there-sentences.

Importantly, the subject of transitives and of non state-based intransitives takes one of the three leftmost positions in (54), while the subject of state-based intransitives takes one of the two rightmost ones. Therefore, (56) fits the independently established subjecthood scale in (54). Appying the macrorole assignment principles, (56) can be rephrased as (56').

(56') V-S agreement: A > U > nonargumental nonmacrorole NP.

The scale in $\left(56^{\prime}\right)$ predicts that $\mathrm{V}-\mathrm{S}$ agreement with the nonargumental noun phrase of existential there-sentences paradigmatically entails $\mathrm{V}-\mathrm{S}$ agreement with undergoer and actor, and $\mathrm{V}-\mathrm{S}$ agreement with undergoer entails $\mathrm{V}-\mathrm{S}$ agreement with actor, but $\mathrm{V}-\mathrm{S}$ agreement with actor does not entail any of the agreement patterns to its right.

For the sake of accuracy, we ought to point out here that the only macrorole of intransitive active accomplishments (cf. 49a) behaves as an undergoer in terms of $\mathrm{V}-\mathrm{S}$ agreement, despite classifying as an actor by (52b1).

(57) Italian
a. Improvvisamente
sono entrati
due ladri. suddenly
be.3PL come.in.MPL
two thief.MPL

Cairo Montenotte, Liguria
b. Impruvisament $i$ sun entroi dui lèdri. suddenly SCL.MPL be.3PL come.in.MPL two thief.MPL
Milan, Lombardy
c. Improvisament gh' è vegnù denter dü lader. suddenly ACL be.3SG come in two thief.MPL
Milan, Lombardy

d. Impruvisament in entrà dü lader suddenly be.3PL come.in two thief.MPL

Grosio, Lombardy
e. $L$ ' é vignì int impruvisament $d u$ ladri.
scl.3sg be.3sG come in suddenly two thief.MPL
'Suddenly, there entered two thieves.'

In fact, the morpho-syntax of active accomplishments in Italo-Romance is more broadly comparable to that of states, achievements and accomplishments, whose macrorole is an

\footnotetext{
${ }^{21}$ Incidentally, this is the case with the passive voice of transitives, where he undergoer is the only macrorole argument in the domain of agreement, which explains why it is the controller, and with psych-verbs of the class of Italian piacere 'like', despite the fact that they have two arguments (see Bentley 2006 for relevant evidence). These issues go beyond the scope of the present article, and will not be dealt with any further.
} 
undergoer. Observe, by way of example, the selection of the perfect auxiliary ESSE 'be' in (57a-e), ESSE 'be' being the perfect auxiliary selected in clauses with an undergoer subject.

The puzzling behavior of active accomplishments has been ascribed to the status of their actor macrorole in logical structure.

\section{$\mathrm{c}^{\prime}$. do' (lader, [move.towards.reference.point ${ }^{\prime}$ (lader)]) \& PROC INGR be-LOC' (denter, lader)}

In particular, the actor of active accomplishments simultaneously holds a high and a low position in logical structure, thus proving to be an affected actor (Bentley 2006: 36). When it comes to split intransitivity phenomena in Italian and Italo-Romance, affected actor must be subsumed under the undergoer umbrella. Observe that the lack of $\mathrm{V}-\mathrm{S}$ agreement with affected actors does not challenge the scale in (54), since affected actors occupy the position called 2nd arg of state pred' (y, $\mathrm{x}$ ), as well as a higher position.

In Table 2 we represent the contrast between $\mathrm{S}-\mathrm{V}$ and $\mathrm{V}-\mathrm{S}$ agreement across dialects.

Table 2. Patterns of finite subject agreement on the Italo-Romance verb

\begin{tabular}{|l|l|l|}
\hline & S-V agreement & V-S agreement when S is pro or... \\
\hline (i) Italian & + & $+\mathrm{A},+\mathrm{U} \mathrm{NP}+$ nonargumental NP \\
\hline (iia) Cairese (C. Montenotte) & + & $+\mathrm{A},+\mathrm{U} \mathrm{NP}$ \\
\hline (iib) Milanese, Fontanellese & + & $+\mathrm{A},+/-\mathrm{U} \mathrm{NP}$ \\
\hline (iii) Grosino (Grosio) & + & $+/-\mathrm{A},-\mathrm{UNP}$ \\
\hline
\end{tabular}

The middle column of Table 2 illustrates generalized $\mathrm{S}-\mathrm{V}$ agreement, which, as we said, satisfies (53). By contrast, proceeding from top to bottom, the right-hand column illustrates the progressive narrowing down of the domains of subject agreement in VS order. In a crossdialectal sense, actor is the default controller, since agreement with undergoer entails agreement with actor (cf. 56'). However, patterns (iib) and (iii) do not grammaticalize - or neutralize paradigmatically - the semantic difference between macroroles in VS order. The rule in (53) would appear to be violated because, if the only macrorole maps to undergoer, V$\mathrm{S}$ agreement is optional in (iib) and ungrammatical in (iii).

The differential treatment of actor and undergoer in patterns (iib) and (iii) follows inactive alignment (Harris and Campbell 1995: 240-241; Van Valin and LaPolla 1997: 274-285), which is a semantically-motivated type of alignment. In fact, $\mathrm{V}-\mathrm{S}$ agreement in patterns (iib) and (iii) is reminiscent of the unaccusative-vs.-unergative divide in intransitives, which has been claimed to be a manifestation of inactive alignment. For example, the selection of the perfect auxiliary in Italian can by and large be explained in terms of the macrorole status of the subject of the clause (Van Valin 1990; Centineo 1986; Bentley 2006). In the next section, we evaluate the proposal that the failure for patterns (iib) and (iii) to abide by rule (53) be explained in terms of this divide.

\section{$4 \mathrm{~V}-\mathrm{S}$ agreement and the Unaccusative Hypothesis}

In this section we consider patterns (iib) and (iii) vis-à-vis the Unaccusative Hypothesis. According to this hypothesis (Perlmutter 1978; Burzio 1986, and subsequent literature), a distinction ought to be drawn between two kinds of intransitive subject: those that are underlying subjects, and occur in so-called unergative predications, and those that are underlying objects, and occur in unaccusative predications. The hypothesis rests on the 
observation that the behavior of unaccusative subjects, unlike that of unergative subjects, is comparable to that of transitive objects.

An important insight of Perlmutter's (1978) original hypothesis, which was subsequently developed in many of its reformulations (Centineo 1986; Van Valin 1990; Levin and Rappaport Hovav 1995; Cennamo 1999; Sorace 2000; Bentley and Eypórsson 2003; Bentley 2006; Diedrichsen 2013; Rosemeyer 2013, among others), is that the unaccusative-vs.unergative split ultimately depends on the semantics of intransitive predicates and of the subject argument. As was briefly mentioned at the end of Section 3, the Aktionsart of the predicate and the macrorole status of the subject are key semantic parameters of split intransitivity in Italo-Romance, with the undergoer or the affected actor of intransitive states, achievements and accomplishments testing out as an unaccusative subject and all other actors testing out as unergative subjects. For this reason we consider patterns (iib) and (iii) here, since these are the patterns that involve a split in V-S agreement between unaffected actors, on the one hand, and undergoers or affected actors, on the other (see Table 2). ${ }^{2}$

In (58) we illustrate $\mathrm{V}-\mathrm{S}$ agreement vis-à-vis a diagnostic of unaccusativity mentioned earlier, namely the alternation of two perfect auxiliaries, derived from Latin ESSE 'be' and HABERE 'have'. As can be seen from these Milanese examples, HABERE 'have' is required in VS constructions with an activity predicate and an unaffected actor controller of $\mathrm{V}-\mathrm{S}$ agreement (cf. 58a), while ESSE 'be' is selected in VS constructions with states (cf. 58b), achievements (cf. 58c) and (active) accomplishments (cf. 58d). The post-verbal undergoer/affected actor does not control agreement obligatorily in the structures with ESSE.

(58) Milan, Lombardy
a. An ciamà $i$ tò gent / tanti malà.
have.3PL called the.PL your people many.MPL patients
'Your parents / Many patients have called.'
b. Ier gh' è / in astà mal $i$ me fiö / tanti fiö.
yesterday ACL be.3SG be. 3PL been unwell the my children.MPL many children
'Yesterday my children / many children were unwell.'
$\begin{array}{llllll}\text { c. In rivà / gh' ̀̀ } & \text { rivà } i \text { tò surèi / di pac. } \\ \text { be.3PL arrived } & \text { ACL be.3SG arrived the your sister.FPL some } & \text { parcel.MPL }\end{array}$
'There arrived yours sisters / some parcels.'

d. Gh' $\grave{e}$ vegnù / in vegni gió $i$ sciur del pian de
ACL be.3SG come be.3PL come.MPL down the.MPL people of.the floor of
sura / di gent del paes de sura.
upstairs some.PL people of.the village of above
'There came down the people from upstairs / some people from the upper village.'

In the light of these facts, it could be argued that the failure for $\mathrm{V}$ to agree with $\mathrm{S}$ is captured by the macrorole status of the latter. Put differently, it could be claimed that the rule in (53), which follows accusative alignment, is superseded in these patterns, in VS order, by a rule that follows inactive alignment. A comparable claim could be couched in a purely syntactic account of unaccusativity whereby the post-verbal S may fail to control agreement depending on its syntax. However, careful observation of the data challenges this hypothesis.

To begin with, the above hypothesis fails to capture the contrast between personal pronouns and other noun phrase classes (see Section 2.2), as the unaccusativity diagnostics

\footnotetext{
22 Incidentally, the relatedness between unaccusative subjects and transitive objects is also captured in terms of Aktionsart and macrorole assignment, in that transitive objects take the lower position in the logical structure of a state, an achievement or an accomplishment, thus being assigned the macrorole undergoer.
} 
do not exhibit a comparable contrast. ${ }^{23}$ Secondly, we are faced with subtle but important mismatches between the absence of $\mathrm{V}-\mathrm{S}$ agreement and the unaccusative side of the intransitivity split. Thus, the optionality of V-S agreement in pattern (iib) (see, for example, $58 \mathrm{~b}-\mathrm{d}$ ) finds no counterpart in perfect auxiliary selection, which is consistently ESSE 'be' with these predicate classes. The optionality of $\mathrm{V}-\mathrm{S}$ agreement, therefore, remains unexplained in an unaccusative account.

In addition, inherent states require $\mathrm{V}-\mathrm{S}$ agreement, despite their testing out as unaccusative in terms of the selection of the perfect auxiliary ESSE 'be'.

(59) Milan, Lombardy

In quest'ann in / *gh' $\grave{e}$ astà intelligent /
in this year be.3PL ACL be3SG been intelligent
alt / biund tüti $i$ me scular.
tall / blond all the my pupil.MPL
'This year all my pupils were intelligent / tall / blond.'

Lastly, in pattern (iii), activities may fail to exhibit V-S agreement despite their consistent behaviour as unergatives in the selection of the perfect auxiliary, see (60a) and (60b). Again, this fact finds no explanation in the unaccusative-vs.-unergative split.

(60) Grosio, Lombardy
a. L' a ciamä al te pa e la toa mama/tanč malä. SCL.3SG have.3 called the your Dad and the your Mum many.PL patients 'Your Mum and Dad / many patients called.'
b. I a ciamä al te pa e la toa mama/tanč malä. SCL.3PL have.3 called the your Dad and the your Mum many.PL patients 'Your Mum and Dad / Many patients called.'

In Sections 5 and 6, we propose an account of the findings outlined in the right-hand column of Table 2 which captures the differential treatment of unaffected actor and undergoer affected actor, as well as the facts highlighted in this section.

\section{Macrorole assignment in presentational focus and subject agreement}

The agreement rule in (53), which crucially hinges on macrorole assignment, appears to be challenged by some of the patterns uncovered in our investigation. Starting from existential there-sentences, the postcopular noun phrase of these sentences does not lend itself to macrorole assignment because it has the predicative function in the logical structure. In turn, the implicit argument cannot take a macrorole because semantically unspecified expressions are not allowed to do so in our framework (Van Valin 2005: 63-64). In the absence of a macrorole argument, we do not expect V to agree with S. Leaving aside the VS constructions in which $\mathrm{S}$ is a personal pronoun, which will be discussed in Section 5.5, this expectation is borne out in patterns (iia-b) and (iii), but not in pattern (i). Observe the contrast between the Italian existential there-sentence in (61a) and its Cairese counterpart in (61b).

\footnotetext{
${ }^{23}$ An anonymous reviewer notes that pronouns have a different position in the syntax of the clause, which would seem to support a syntactic account. However, the point made above, i.e., that other unaccusativity diagnostics are orthogonal to the noun vs. pronoun contrast in VS order remains valid. This suggests that the facts uncovered by our investigation cannot be fully captured in terms of the unaccusative- vs.-unergative contrast.
} 
(61) Italian

a. $C i$ sono dei mobili vecchi.

ACL be.3PL some furniture.MPL old.MPL

$a^{\prime}$. be' (x, [mobili vecchi])

Cairo Montenotte, Liguria

b. $U \quad i \quad \grave{e} \quad d i$ mobili vègi.

ESCL ACL be.3SG some furniture.MPL old.MPL

'There is some old furniture.'

$\mathrm{b}^{\prime}$. $\mathbf{b e}^{\prime}(\mathrm{x}$, [mobili vegi])

All the other VS constructions analyzed above ought to license macrorole assignment, and hence are predicted by (53) to exhibit $\mathrm{V}-\mathrm{S}$ agreement. This prediction is borne out in pattern (i), as well as in (iia), exception being made by inverse locatives. Indeed, the post-copular argument of inverse locatives does not control V-S agreement in (iia) despite its occurrence in an undergoer position in logical structure, if the hypothesis tentatively put forward above is correct, see (46a), (46b) and (62').

(62) Cairo Montenotte, Liguria

U i è I MATOTI (a ca).

ESCL ACL be.3SG the boy.MPL at home

'The boys are there (at home).'

(62') be-LOC' (ca, matoti)

Furthermore, the same prediction of (53) is not borne out in patterns (iib) and (iii). To understand these puzzling results, it is helpful to take a closer look at pattern (iib).

\subsection{The conflict between grammatical and anaphoric agreement}

On a par with (iia), (iib) rules out grammatical agreement in both existential and locative there-sentences. In constructions with a contentful verb, we found a split that correlates systematically with the semantic properties of the predicate and, consequently, of the argument that is the agreement source. Specifically, we found systematic V-S agreement with transitives and intransitive activities, which take an unaffected actor macrorole. By contrast, $\mathrm{V}-\mathrm{S}$ agreement was found to be optional with intransitive state-based predicates, which take an undergoer or affected actor macrorole. A nonreferential clitic that is formally identical to the pre-copular clitic of existential there-sentences systematically co-patterns with the lack of agreement.

Despite its etymology, the said clitic does not pick out a referential location, as suggested by the fact that it is not restricted to co-occur with verbs with a particular kind of deixis and it is also required with nondeictic verbs like 'die' (cf. 63a) and 'break out' (cf. 63b).

(63) Milan, Lombardy

a. Gh' è mort tanti suldà.

ACL be.3SG died many soldier.MPL

'There died many soldiers.'

Fontanelle di Boves, Piedmont

b. Enche mumant sì $j$ a st-ciupà tante guare.

in DEM moment DEM ACL have.3SG broken.out many war.FPL 
'In that period there broke out many wars.'

In fact, in the presence of an overt locative phrase within the clause, the nonreferential clitic does not take this phrase as its antecedent. Consider the contrast between the locative adverb $l i$ 'there' in (64a) and the ghe in the VS construction in (64b).

(64) Milan, Lombardy

a. Gh' em de andà a cà perchè gh' è rivà lì $i$ fiö.

ACL have.1PL of go to home because ACL be.3SG arrived there the child.MPL

'We have to go home because the kids have arrived there (at home).'

b. Gh' em de andà $a$ cà perchè gh' ’̀ rivà $i$ fiö.

ACL have.1PL of go to home because ACL be.3SG arrived the children.MPL

'We have to go home because the kids have arrived / have arrived here /

have arrived there (at home or somewhere else).'

Whereas $l i$ 'there' in (64a) can only refer to the overt antecedent $c \dot{a}$ 'home', the ghe of gh'è rivà in (64b) does not. Rather, this ghe is the anaphora (see note 5) of a spatio-temporal domain that is implicit (i.e., nonreferential and semantically unspecified) and discoursedependent (i.e., understood in the discourse context).

The fact that the clitic can co-occur with a locative adverb or a locative phrase within the clause also suggests that it has no locative meaning of its own. If it had its own locative meaning, the result would be either a clash in deixis or an illicit case of clitic doubling (see note 7). Observe that there is no intonational break before the locative prepositional phrase in $(65 a-b)$.

(65) Milan, Lombardy

a. Gh' è rivà $i$ mè cüsit a la stasiun.

ACL be.3SG arrived the my cousins a the station

'There arrived my cousins at the station.'

Fontanelle di Boves, Piedmont

b. $J$ a arivà $i$ matàt ala stasiun.

ACL have.3SG arrived the kids athe station

'There arrived the kids at the station.'

Therefore, similarly to existentials, the other VS constructions with the locative clitic are also context-dependent. This means that their meaning can only be understood within an implicit spatio-temporal domain whose deixis is provided by the discourse context. Following the standard representation of locative and temporal adpositions (Van Valin and LaPolla 1997: 159), we represent this domain as a spatio-temporal modifier of the whole logical structure of the main verb and its argument.

(66) Milan, Lombardy

Gh'è mort tant suldà.

ACL be.3SG died many soldiers

'There died many soldiers.'

(66') be-LOC' (x, [PROC INGR dead' (tant suldà)])

In semantics-syntax linking, the argument tant suldà 'many soldiers' can be assigned a macrorole qua argument of the predicate 'die'. However, it can also fail to receive a macrorole because it co-occurs together with the verb within the square brackets. According 
to Van Valin and LaPolla (1997: 159), the contents of the square brackets constitute the second argument of a locative preposition. In this case, this is not an overt preposition, but an implicit spatio-temporal modifier spelled out by the anaphoric clitic alone. This analysis captures the optional lack of macrorole assignment, since $\mathrm{S}$ is not only an argument of the verb, but, together with the verb, it is an argument of the implicit modifier. Failure of macrorole assignment results in absence of V-S agreement, which is testified by the default verbal inflection.

The above proposal couches in Role and Reference Grammar parlance the insight that VS constructions involve a covert topic or an anchor to the universe of discourse (Benincà 1988; Saccon 1992, 1993; Erteschik-Shir 1997; Pinto 1997; Manzini and Savoia 2005/III: 75-80; Parry 2013; Corr 2016). In addition, our proposal formalizes the notion of argument integration in presentational constructions, which is a strategy of cognitive and communicative economy whereby "[...] the whole syntagm is introduced as one unit of information, 'integrating' its parts into one 'globally new' unit" (Fuchs 1980: 449, cited in Sasse 2006: 258; see also Lamrecht 2000; Zeller 2013). Importantly, Role and Reference Grammar explicitly claims that discourse can intervene at any stage in semantics-syntax and syntax-semantics linking (Van Valin 2005: 1-2). What we observe in Gallo-Italian VS constructions is a manifestation of the role of discourse in the linking. Specifically, we claim that discourse intervenes when the logical structure of the predicator is retrieved from the lexicon in the linking (Van Valin 2005: 108), embedding it in the wider logical structure of an implicit spatio-temporal modifier that receives its value from discourse.

The ban on inherent states (recall that these are deemed to be odd or ungrammatical in VS order, and require V-S agreement if accepted) can now be explained as follows. If as we propose the VS constructions lacking grammatical agreement in pattern (iib) are predications that hold within a discourse-dependent spatio-temporal domain, they are spatially and/or temporally bounded. They thus exhibit contingent states, which predicate stages. Contrastingly, inherent states predicate properties of individuals, and hence do not lend themselves to occur in this construction. The result states that are the outcome of events of change-of-state and change-of-location, see (33) and (34), are also contingent states, and thus lend themselves to the construction under discussion. Activities, on the other hand, are [-telic] and thus are not as readily available. Nonetheless, it cannot be claimed that they are banned from the construction (witness pattern iii) and, hence, the contrast between accomplishment and achievements, on the one hand, and activities, on the other, must primarily depend on the unaffected actor status of the source of agreement with activity verbs, as predicted by the scale of subjecthood in (54). ${ }^{24}$

Importantly, the systematic occurrence of the nonreferential locative clitic in the structures without V-S agreement suggests that a different type of agreement obtains here. We claim that the clitic spells out agreement of the verb with the implicit spatio-temporal modifier. We call this agreement anaphoric, since it is not agreement with a subject, but rather with a discourse-dependent topic. Crosslinguistically, anaphoric agreement is known to rely on pragmatic properties of the antecedent, such as topicality, and to be neither inherently clause internal nor syntactic (Bresnan and McHombo 1987). These are properties of anaphoric agreement in the dialects of our sample. We should note, however, that the type of agreement under discussion here differs from the anaphoric agreement that is found in heard-marking languages in two principal respects. First, the anaphoric clitic of the dialects of our sample is not referential. Secondly, there is no co-variance of grammatical features. Rather, the

24 On the basis of the secondary evidence, we note that a locative clitic can surface with nonagreeing activity verbs in other dialects (Saccon 1992, 1993; Parry 2013: 540-544). We note, however, the examples reported in the literature normally exhibit a locative phrase in sentence initial position. This suggests that, in this case, the locative clitic resumes the locative phrase. 
predication takes the spatio-temporal value of an implicit spatio-temporal modifier, as signalled by the nonreferential anaphoric clitic. Put differently, this is deictic agreement. Observe in passing that verb agreement with a spatio-temporal domain is witnessed in other, unrelated, languages. We refer, for example, to Mithun's (2003: 265-266) discussion of the ambient prefix in Navajo.

Anaphoric agreement can now be argued to occur in existential there-sentences not only in pattern (iib), but also in pattern (iia). In both patterns, these copular structures fail to exhibit grammatical V-S agreement, as is expected on the basis of (53). The nonreferential clitic spells out anaphoric agreement with the implicit argument of these constructions (cf. 61).

As for locative there-sentences (cf. 62), in Section 3 we tentatively assumed that inverse locatives share the same logical structure as other copular locatives (cf. 46). We now revisit this analysis and claim that, as a result of the intervention of discourse in the first step of the semantic-syntax linking, the logical structure of inverse locatives is construed as in $(67 \mathrm{a}-$ b) $\sim\left(67 a^{\prime}-b^{\prime}\right)$.

(67) Milan, Lombardy
a. Gh' è $\quad I \quad F I O ̈ \quad$ (in cà).
$\mathrm{ACL}$ be.3SG the boy.MPL in home
'The boys are there (at home).'
a'. be-LOC' (cà, [fiö]).
Fontanelle di Boves, Piedmont
b. $J \quad a \quad$ I $\left.\quad \begin{array}{lllll}\text { MATAT } & (a & \mathrm{ca}\end{array}\right)$.
ACL have.3SG the. MPL boys at home
'The boys are there (at home).'
b'. be-LOC' (ca, [matat]).

On a par with the logical structure of all copular locatives (cf. 46a'), this logical structure describes a predicative relation between a locative expression and a nonlocative one. However, since the locative expression is topical and salient, and the presence of the nonlocative expression is predicated about it, the locative expression is treated as a spatiotemporal modifier in logical structure. In turn, the focal expression is embedded in the topical location as an argument of a locative adposition. The anaphoric clitic takes the topical locative phrase as its antecedent and spells out anaphoric, deictic, agreement of the copula with this phrase.

In the next section, we provide the historical context of the findings and analyses presented in this section.

\subsection{Subject clitics and anaphoric agreement}

The fact that the competition between grammatical and anaphoric agreement (patterns iia-b) solely characterizes northern Italian dialects is not trivial. Typologically, these dialects differ from the central and southern ones, in that they not only spell out grammatical agreement inflectionally, but also with subject clitics (see Section 2.1). Included in the pre-verbal subject-clitic series are nonnominative, deictic, clitics (Poletto 1993, 2000; Poletto and Tortora 2016). Indeed, Tortora $(1997,2014)$ noted that, in the Piedmontese dialect of Borgomanero, goal-entailing verbs of inherently directed motion (such as rivè 'arrive', gni 'come', gnìturnè ndre 'come back', gni denti 'enter') can co-occur with the clitic sequence $n g h . . . g h i$ in the present and past perfect, when $\mathrm{S}$ follows $\mathrm{V}$, while other verbs of motion do not admit this clitic sequence. Finite number agreement is not controlled by the post-verbal 
noun phrase in the presence of $n g h . . . g h i$, as is shown by the grammaticality contrast between (68a) and (68b).

(68) Borgomanero, Piedmont
a. Ngh è rivà-gghi do mati.
LCL be.3SG arrived-LOC two.F girl
b. ${ }^{*} N g h$ (j) $n$ rivaj-gghi do mati.
LCL SCL be.3PL arrived.PL-LOC two.F girls
'There arrived two girls.'

(Tortora 1997: 56-57)

Tortora (1997: 56, 2014: 31) developed a syntactic account that takes the verb to agree with a phonologically null element in subject position, which is co-indexed with the locative subject clitic in a lower syntactic position.

By contrast with Borgomanerese, pattern (iib) exhibits the nonreferential locative clitic, in concomitance with the absence of $\mathrm{V}-\mathrm{S}$ agreement in constructions with a much wider range of verbs. We argued that this is not grammatical agreement with a subject, but rather anaphoric agreement with an implicit discourse-dependent modifier, which provides the spatio-temporal co-ordinates of the predication. ${ }^{25}$

The comparative analysis of Borgomanerese and the dialects with pattern (iib) lends support to Parry's (2013) claim (drawing on Ciconte 2010) that the locative clitic of VS constructions in Gallo-Italian dialects must have grammaticalized from the locative argument of a restricted class of directed motion predicates (e.g., 'arrive'), thus spreading first to all locatives and then to constructions with other types of predicate, where it is neither argumental nor referential.

In Parry's (2013) opinion, this process occurred as an epiphenomenon of the loss of the V2 order of Medieval Romance (Benincà 1994b) and the concomitant establishment of the subject in preverbal position. A consequence of this process was the reanalysis of clauseinternal resumptive pronouns linked to dislocated noun phrases as subject-clitic agreement markers (Poletto 1993, Parry 1993). In turn, the resumptive clitics that were originally coreferent with left-dislocated locative phrases became nonreferential clitics. See the pronoun $g$ ', which is co-referent with in quela 'in that one', in the following early Ligurian example.

(69) Old Ligurian

In quela, [...], l' omo g' ̀̀ amonio [...].

in that the man ACL be.3SG warned

'In that one (house), the man is warned (there)...'

(Dialogo de Sam Gregorio, 225: 10-11, cited in Parry 2013: 528)

In our analysis, the nonreferential locative clitics are agreement markers, similarly to personal subject clitics, but, differently from these clitics, they are markers of anaphoric agreement. The establishment of this pattern is concomitant with the retrenchment of grammatical V-S agreement, which, in the common ancestor of the relevant dialects, Latin, was fully grammaticalized. Compared with (iib), (iia) testifies in synchrony to a return to

\footnotetext{
${ }^{25}$ As noted by an anonymous reviewer, our data could also be analysed in terms of syntactic agreement with a null operator in the left periphery of the clause. We do not deny this. However, our findings support the differentiation between grammatical agreement with a subject and anaphoric agreement with a discourse topic, which may remain unnoticed in the said account. Also, unless verb semantics is factored in, the subtle contrasts in agreement between constructions that can all be labelled as unaccusative remain unexplained, as does the range of crossdialectal variation brought to light by our investigation.
} 
generalized grammatical agreement regardless of the pragmatico-semantic properties of the predicate and its argument, while still exhibiting anaphoric agreement in there-sentences (see note 12). The resilience of copular there-sentences to grammatical agreement and the contrast between these sentences and those with contentful verbs are explained by the status of the antecedent of the anaphoric clitic as an inherent component of the logical structure of these sentences, see (61) and (62). This status is also cogent in the analysis of pattern (iii). By contrast with pattern (iia), (iii) witnesses a change in the opposite direction, with grammatical agreement being much more constrained than in the other patterns. It is to pattern (iii) that we now turn.

\subsection{Subject clitics and the loss of grammatical agreement}

Pattern (iii) contrasts with (iia-b) in that it shows no correlation between the lack of $\mathrm{V}-\mathrm{S}$ agreement and the presence of a nonreferential locative clitic. In (iii), there-sentences exhibit the nonreferential locative clitic ghe, regardless of agreement.

(70) Grosio, Lombardy
a. Al gh' é mubilia veğa.
SCL.3SG ACL be.3 furniture.FSG old.FSG
'There is some old furniture.'
b. Maria l' é miga de perlé: ghe son mi.
Mary SCL.3SG be.3SG NEG of by her ACL be.1SG I
'Mary is not alone: there is me.'
c. Al gh'é I RÀIS (a ché).
SCL.3SG ACL be. 3 the children.MSG at home
'The boys are there (at home).'

By contrast, VS constructions with a contentful verb lack the locative clitic, again, regardless of agreement: the latter is missing in (71a), optional in (71b) and obligatory in (71c).

(71) Grosio, Lombardy
a. Finalment $l, \quad / *_{i} \quad \grave{e}$ rivä $i$ ràis.
finally SCL.3SG SCL.3PL be.3 arrived the children.MSG
'Finally, there arrived the children.'
b. $L$ a / $i \quad a$ durmi tanč ràis.
SCL.3SG have.3 SCL.3PL have.3 slept many children.MSG
'Many children have slept.'
c. Quel cinema, $i \quad l$ ' a vedu tantisima gent.
that film SCL.3PL OCL have.3 seen many.SUPERL people
'That film, many people have seen it.'

In the absence of $\mathrm{V}-\mathrm{S}$ agreement, pattern (iii) exhibits an invariant third-person-singular subject clitic $((a) l$ in $70 \mathrm{a}, \mathrm{c}$ and $71 \mathrm{a}-\mathrm{b})$. Importantly, this default personal clitic does not appear in patterns (iia-b), although some of the relevant dialects can exhibit an expletive clitic form (see note 4$)$.

In the light of the cross-dialectal comparison, we claim that, in pattern (iii), ghe simply spells out the implicit argument of existential there-sentences, see (70a) and (70b), and the locative modifier in the logical structure of inverse locatives (cf. 70c), while a default, 
invariant, subject clitic signals the absence of grammatical subject agreement in the sense of (53).

VS constructions with state-based predicates, which categorically reject grammatical agreement, must be assumed to be embedded in the logical structure of an implicit spatiotemporal modifier in (iii), as is the case with the other patterns. This proposal is shown in (71a').

\section{(71) a'. be-LOC' (x, [INGR be-at' (i ràis)])}

As was explained above, this logical structure does not require macrorole assignment, and, indeed, in pattern (iii) a macrorole is not assigned. Consequently, there is no V-S agreement, as testified by the default exponence on the verb, as well as the default personal subject clitic. Crucially, in pattern (iii) anaphoric agreement also fails to obtain, as signalled by the lack of a deictic clitic in subject-clitic position.

As for VS constructions with non state based predicates, although our cross-dialectal evidence does not testify to the presence of an implicit spatio-temporal modifier (though see note 24), others have claimed that all sentence-focus constructions involve a covert topic of some kind, sometimes called Subject of Predication (Saccon 1992, 1993; Erteschik Shir 1997, etc.). Capitalising on the findings of others, we thus claim that macrorole assignment may optionally fail because these sentence-focus structures are not predications about the postverbal argument. Rather, the whole eventuality described of $\mathrm{V}$ and $\mathrm{S}$ is a predication about a covert topic.

In the light of the fact that non state-based predicates did exhibit V-S agreement in the speech of the older generations, pattern (iii) witnesses an on-going process of retrenchment of grammatical subject agreement. Crucially, from our perspective, this process follows the scales in (54) and (56), currently leaving the highest macrorole of biargumental, transitive, constructions as the only compulsory agreement controller in sentence focus. In addition, pattern (iii) does not license anaphoric agreement either with state-based or with non statebased predicates, but rather indicates the lack of grammatical subject agreement by a default clitic in subject position.

\subsection{The limiting case of grammatical agreement}

Pattern (i) only poses a challenge to the rule in (53) in the case of existential there-sentences, where the postcopular noun phrase does not lend itself to macrorole assignment because it has the predicative function in logical structure. In the absence of macrorole assignment, this noun phrase is expected not to control agreement. This expectation, however, is not borne out by the Italian data.

(72) Italian

Ci sono dei mobili vecchi.

ACL be.3PL some furniture.MPL old.MPL

'There is some old furniture.'

(72') be'(x, [mobili vecchi])

We claim that this pattern illustrates the limiting case of grammatical subject agreement. In the absence of a macrorole argument, the only available noun phrase endowed with its own overt agreement features is pressed into service as the controller of grammatical agreement. In support of this claim, we observe that existential there-sentences with INDE-cliticization, 
where the agreement features of the source may be covert, are the only construction where grammatical V-S agreement is optional (particularly in the informal registers).

(73) Italian

(Problemi)ce ne sono/ce n' è tre.

problems ACL INDE be.3PL ACL INDE be.3SG three

'(Problems) there are three.'

Elsewhere, pattern (i) abides by the agreement rule in (53), in that it consistently assigns the relevant macrorole(s) to the core argument(s) of the predicator, and treats the highest argument as the controller.

\subsection{Anaphoric agreement across dialects: personal pronouns}

In all the dialects investigated personal pronouns are agreement controllers independently of discourse and word order, and regardless of whether the verb is a copula or a contentful verb.

(74) Italian

a. Alle due siete arrivati voi.

at.the two be.2PL arrived.MPL you.PL

'At 2 o'clock you arrived.'

Milan, Lombardy

b. Pö si rivà vui alter.

thenbe.2PL arrived you.PL other

Cairo Montenotte, Liguria

c. $P \ddot{o} \quad i \quad$ sei rivòi vui otri.

then SCL.2PL be.2PL arrived.MPL you.PL other

Fontanelle di Boves, Piedmont

d. Curaseve arivé vate.

then be.2PLarrived.PL you.PL

Grosio, Lombardy

e. Dopu sef rivä valtri.

then be.2PL arrived you.PL

'Then you (pl) arrived.'

Agreement with personal pronouns can be anaphoric (Lehmann 2014 [1982]: 50) and hence beyond the scope of the rule in (53). This means that the agreement exponence (the subject clitic and/or the verbal inflection) shares the same anaphoric properties as the personal pronoun itself. Therefore, the agreement exponence does not spell out grammatical agreement with the pronoun, but rather, together with the pronoun, it spells out anaphoric or deictic (Bresnan and Mchombo 1987: 748) agreement with an antecedent provided within the Speech Act or by the discourse context.

To be sure, in two of the dialects investigated, third person pronouns turned out to pattern as noun phrases.

(75) Fontanelle di Boves, Piedmont
a. Curaj arivà lur... then ACL have.3SG come they
Asti, Piedmont 


\section{b. Pö $\hat{r}^{\prime} \quad \grave{e}$ amni-ji lur atru... \\ then SCL.3SG be.3SG come-ACL they other}

'Then they arrived...'

Unlike the first and second persons, which are uniquely identified in the context of the speech act by means of the verbal inflection alone (Benincà 2007: 42), the third person refers to established and salient discourse participants outside the speech act and is not uniquely identified by the verbal inflection. Therefore, the third person is lower than the first and the second persons on the specificity scale that is known to be relevant to subjecthood and to subject agreement across languages (Benveniste 1966; Keenan 1976; Givón 1976; Mithun 2003; Bentley 2013). The different treatment of the third person in the dialects of Asti and Fontanelle suggests that, in these dialects, the domain of anaphoric agreement with the antecedent of a personal pronoun is narrower than in the other dialects and, specifically, confined to Speech Act Participants. Significantly, the cross-dialectal variation does not violate the known scale of specificity, in that, in agreement with Tortora's (1997) pioneering findings, we did not found any dialects where there is no agreement with first and second person pronouns, but there is agreement with third person pronouns.

\subsection{Interim conclusion}

In this section we have proposed that the variation in $\mathrm{V}-\mathrm{S}$ agreement is to be captured in terms of macrorole assignment or failure thereof. This proposal formalizes the insight that, in sentence-focus constructions, a core argument may be treated as part of the predicate, thus failing to behave as the controller of grammatical subject agreement (Fuchs 1980: 449; Sasse 2006: 258; see also Lambrecht 2000; Zeller 2013). The treatment of a core argument as part of the predicate occurs in presentational focus because this type of structure presupposes an implicit topic, as has been claimed in previous literature. Using first-hand Gallo-Italian evidence, in this paper we have identified and investigated a cluster of presentational-focus constructions with a contingent or result state whose implicit topic has properties that are comparable to those of the implicit spatio-temporal argument of existential there-sentences. We have proposed that this topic is embedded in logical structure as an implicit modifier of the whole predication of $\mathrm{V}$ and $\mathrm{S}$. In this logical structure, $\mathrm{S}$ may fail to receive a macrorole because of the position it takes in logical structure. A comprehensive analysis of the typology of implicit topics in sentence-focus constructions is to be left to future research.

Importantly, the logical structures proposed above are not intended to be dialect-specific. Rather, the cross-dialectal differences uncovered and analyzed in this paper arise from parametric variation in macrorole assignment in structures with an implicit topic that are found across all dialects. We have also uncovered cross-dilaectal differences in anaphoric agreement with the said topic.

Our findings clearly show that agreement is sentitive to the semantics of $\mathrm{V}$ and its entailments on S, although different dialects exhibit different degrees of such sensitivity. This issue is discussed in the next section.

\section{Semantic parameters of subject agreement}

The variation in verb agreement that is observed in Italo-Romance illustrates various degrees of grammaticalization of subject agreement. We claimed that, in the dialects of our sample, pattern (iii) amounts to maximally constrained grammatical subject agreement and pattern (i) to maximally grammaticalized subject agreement. 
While the existing literature has placed emphasis on the discourse constraints on subject agreement, highlighting the implication between V-S and S-V agreement (Lehmann 2014 [1982]: 50), this study has explored the relation between discourse and the semantic properties of the controller, which ultimately depend on the semantics of the predicate. Two principled predictions arise from our findings. First, if $\mathrm{V}-\mathrm{S}$ agreement is found in copular constructions, it will also be found in constructions with a contentful verb; second, if $\mathrm{V}-\mathrm{S}$ agreement is found with intransitive state-based predicates, it is also found with intransitive non state-based predicates. The first prediction is based on the analysis of existential theresentences as structures with an implicit argument and a predicative noun phrase (Francez 2007 and subsequent literature). The second prediction fits the scale of subjecthood independently proposed by Van Valin and LaPolla (1997: 175) for accusative alignment.

(76) Arg of DO $>1$ st $\arg$ of do' $(x, \ldots)>1$ st $\arg$ of pred $^{\prime}(x, y)>2$ nd $\arg$ of pred' $(x, y)>\arg$ of state pred' $(\mathrm{x})$

The cross-dialectal variation discussed in this paper cannot be captured without reference to this scale. Pattern (i) treats all the argument types in (76) as controllers, regardless of their role in discourse (and hence their position in syntax). In fact, in there-sentences that lack a semantically specified argument, a referential expression endowed with agreement features is treated as the controller. Sub-pattern (iia) treats all the argument types in (76) as controllers, exception being made for the argument of the state predicate of inverse locatives. We claimed that this is a focal expression which fails to be treated as the macrorole argument of the construction because it is embedded in the topical location as the argument of a locative adposition. The rule of grammatical agreement does not apply and anaphoric agreement with the topical location obtains. The same occurs in sub-pattern (iib), where anaphoric agreement optionally extends to constructions with contingent and result states. In terms of (76) the two rightmost argument types optionally fail to control agreement as a result of failure of macrorole assignment.

The development of anaphoric agreement in patterns (iia-b) is concomitant with the rise of subject clitics. We uncovered a contrast in $\mathrm{V}-\mathrm{S}$ agreement between inherent and contingent or result states. This contrast highlights affectedness as a lexical entailment that is relevant to subject agreement. The relevance of affectedness emerges even more clearly from the contrast between unaffected actors and affected actors in patterns (iia-b), as well as (iii). In (iii), all the argument types in (76) may fail to control subject agreement in presentational focus. However, the leftmost ones only do so optionally in intransitive predications, while systematically controlling subject agreement in transitive predications, where they constitute the highest of two macrorole arguments, i.e., the one that is not affected. In sum, our findings clearly indicate that unaffected actor is the default type of controller, in accordance with the independently established principle of accusative alignment.

While the contrast between $\mathrm{S}-\mathrm{V}$ and $\mathrm{V}-\mathrm{S}$ agreement testifies to the sensitivity of subject agreement to discourse, the cross-dialectal variation in $\mathrm{V}-\mathrm{S}$ agreement is evidence of its sensitivity to the semantic entailments of the source. The generalization of subject agreement, as witnessed by pattern (i), amounts to the lack (or loss) of this sensitivity. In the last analysis, this study contributes to an understanding of subject agreement as the grammaticalization of semantic-relation, as well as pragmatic-role, contrasts.

\section{Conclusion}


In this paper, we have explored subject agreement in the light of first-hand evidence of dialect microvariation in Italo-Romance. The dialects under examination support the known implicative relation between V-S and S-V agreement (Moravcsik 1978, Lehmann 1982). At the same time, the variation in $\mathrm{V}-\mathrm{S}$ agreement that is found in many northern dialects is reminiscent of the unaccusative unergative divide. With our investigation, we uncovered a fine-grained range of variation, which is not entirely captured in terms of this divide. Building upon Parry (2013), we claimed that, as a result of the rise of subject clitics, a group of northern, Gallo-Italian, dialects exhibits an unresolved synchronic conflict between anaphoric agreement with a topic and grammatical agreement with a subject. The former type of agreement obtains when the source of grammatical agreement is not presupposed, thus following the target, and, in addition, it ranks below the dialect-specific threshold on an independently established semantic scale of subjecthood (Van Valin and LaPolla 1997: 175; Van Valin 2005: 108). The same semantic parameters of subjecthood prove to be at work in other northern dialects, in which default subject-clitic agreement occurs instead of anaphoric agreement. Finally, in Italian, V-S agreement is fully grammaticalized and hence unaffected by the discourse role or the semantic entailments of the controller.

Following Van Valin's (2005) linking algorithm and rule of finite verb agreement, we proposed an analysis of $\mathrm{V}-\mathrm{S}$ agreement in terms of macrorole assignment or lack thereof. Our proposal formalizes the insight that, in sentence-focus constructions, a core argument may be treated as part of the predicate, thus failing to behave as the controller of subject agreement (Fuchs 1980; Lambrecht 2000; Sasse 2006, etc.). The treatment of a core argument as part of the predicate occurs in presentational focus because this focus structure presupposes an implicit topic (Benincà 1988; Saccon 1992; Erteschik-Shir 1997, and subsequent literature). We distinguished existential there-sentences, where the implicit topic is a spatio-temporal argument of the existential pivot, from a cluster of VS constructions in which the implicit topic is a spatio-temporal modifier of the whole predication.

An anonymous reviewer noted that what we call anaphoric agreement may as well be analysed as syntactic agreement with a null operator in the position of scene setters in the left periphery of the clause. We do not deny that such a syntactic account would capture the dialect-specific facts under discussion. We claim, however, that unless verb semantics is factored into the account of $\mathrm{V}-\mathrm{S}$ agreement, the range of crossdialectal variation brought to light by our investigation remains unexplained, while the role of the semantic entailment affectedness may pass unnoticed. Moreover, our findings, and the approach taken in this paper, lend support Bresnan and Mchombo's (1987) differentiation between grammatical agreement with a subject and anaphoric agreement with a discourse topic.

The single most important claim put forward in the paper is that the variation in subject agreement cannot be captured without reference to an independently established scale of subjecthood that is based on argument positions in semantic representation, and, hence, on the lexical entailments of arguments. Our findings clearly indicate that unaffected actor is the default type of controller in accusative alignment. In the last analysis, this study contributes to an understanding of subject agreement as the grammaticalization of semantic-relation, alongside pragmatic-role, contrasts.

\section{References}

Abbott, Barbara. 1992. Definiteness, existentials, and the "list" Interpretation. In Chris Barker and David Dowty (eds.), Proceedings of Semantics and Linguistic Theory II, 116. Columbus, OH: The Ohio State University.

Abbott, Barbara. 1993. A pragmatic account of the definiteness effect in existential sentences. Journal of Pragmatics 19. 39-55. 
Benincà, Paola. 1983. II clitico "a" nel dialetto padovano. In Paola Benincà, Manlio Cortelazzo, Aldo Prosdocimi, Laura Vanelli \& Alberto Zamboni (eds.), Scritti linguistici in onore di Giovan Battista Pellegrini, 25-32. Pisa: Pacini.

Benincà, Paola. 1988. L'ordine degli elementi della frase. Costruzioni con ordine marcato degli elementi. In Lorenzo Renzi (ed.), Grande grammatica italiana di consultazione. Volume 1: La frase. I sintagmi nominale e preposizionale, 129-194. Bologna: il Mulino.

Benincà, Paola. 1994a. Tipologia dei pronomi soggetto nelle lingue romanze. In Paola Benincà, La variazione sintattica: Studi di dialettologia romanza, 195-211. Bologna: il Mulino.

Benincà, Paola. 1994b. Punti di sintassi comparata dei dialetti italiani settentrionali. In Paola Benincà, La variazione sintattica: Studi di dialettologia romanza, 105-138. Bologna: il Mulino.

Benincà, Paola. 2001. The Position of topic and focus in the left periphery. In Guglielmo Cinque and Giampaolo Salvi (eds.), Current studies in Italian syntax. Essays offered to Lorenzo Renzi, 39-64. Amsterdam: Elsevier.

Benincà, Paola. 2007. Clitici e ausiliari: gh ò, z é. In Delia Bentley and Adam Ledgeway (eds.), Sui dialetti italo-romanzi. Saggi in onore di Nigel B. Vincent (Special supplement number 1 to The Italianist 27), 27-47. King's Lynn, Norfolk: Biddles Ltd.

Bentley, Delia. 2006. Split intransitivity in Italian. Berlin \& New York: Mouton de Gruyter.

Bentley, Delia. 2013. Subject canonicality and definiteness effects in Romance there sentences. Language 89(4). 675-712.

Bentley, Delia. 2015a. Existentials and locatives in Romance dialects of Italy: introduction. In Delia Bentley, Francesco M. Ciconte \& Silvio Cruschina, Existentials and locatives in Romance dialects of Italy, 1-42. Oxford: Oxford University Press.

Bentley, Delia. 2015b. Predication and argument realization. In Delia Bentley, Francesco M. Ciconte \& Silvio Cruschina, Existentials and locatives in Romance dialects of Italy, , 99-160. Oxford: Oxford University Press.

Bentley, Delia and Pórhallur Eypórsson. 2003. Auxiliary selection and the semantics of unaccusativity. Lingua 114. 447-471.

Benveniste, Émile. 1966. Problèmes de linguistique générale. Paris: Gallimard.

Bernini, Giuliano. 2012. Il clitico a nell'italo-romanzo settentrionale: osservazioni metodologiche. In Vincenzo Orioles (ed.), Per Roberto Gusmani. Linguistica storica e teorica. Studi in ricordo, 269-282. Udine: Forum.

Brandi, Luciana and Patrizia Cordin. 1989. Two Italian dialects and the null subject parameter. In Osvaldo Jaeggli and Kenneth Safir (eds.), The null subject parameter, 111-142. Dordrecht: Foris.

Bresnan, Joan and Sam A. Mchombo. 1987. Topic, pronoun and agreement in Chichewa. Language 63. 741-782.

Burzio, Luigi. 1986. Italian syntax. A government-binding approach. Dordrecht: Kluwer.

Cardinaletti, Anna and Lori Repetti. 2010. Proclitic vs enclitic pronouns in northern Italian dialects and the null-subject parameter. In Roberta D'Alessandro, Adam Ledgeway d Ian Roberts (eds.), Syntactic variation. The dialects of Italy, 119-134. Cambridge: Cambridge University Press.

Carlson, Gregory. 1977. A unified analysis of the English bare plural. Linguistics and Philosophy 1. 413-56.

Cennamo, Michela. 1999. Late Latin pleonastic reflexives and the Unaccusative Hypothesis. Transactions of the Philological Society 97. 103-150.

Centineo, Giulia. 1986. A lexical teory of auxiliary selection in Italian. Davies Working Papers in Linguistics 1. 1-35. 
Ciconte, Francesco M. 2010. Existential constructions in the early Italo-Romance vernaculars. Manchester: The University of Manchester thesis.

Ciconte, Francesco M. 2015. Historical context. In Delia Bentley, Francesco M. Ciconte \& Silvio Cruschina, Existentials and locatives in Romance dialects of Italy, 217-260. Oxford: Oxford University Press.

Corbett, Greville. 2003. Agreement: the range of the phenomenon and the principles of the Surrey database of agreement. Transactions of the Philological Society 101(2). 155202.

Corbett, Greville. 2006. Agreement. Cambridge: Cambridge University Press.

Cornilescu, Alexandra. 2009. Restructuring strategies of the Romanian verb $f i$ 'be' and the analysis of existential sentences. In Georg A. Kaiser and Eva-Maria Remberger (eds.), Null subjects, expletives and locatives in Romance, 199-230. Konstanz: Universität Konstanz, Konstanzer Arbeitspapiere des Fachbereichs Sprachwissenschaft (No. 123).

Corr, Alice. 2016. Wide-focus subject-verb inversion in Ibero-Romance: a locative account. Glossa: a Journal of General Linguistics 1(1): 11. 1-33

Cruschina, Silvio. 2012. Focus in existential sentences. In Valentina Bianchi and Cristiano Chesi (eds.), Enjoy linguistics! Papers offered to Luigi Rizzi on the occasion of his 60th Birthday, 77-107. Siena: CISCL Press.

Cruschina, Silvio. 2015. Focus structure. In Delia Bentley, Francesco M. Ciconte \& Silvio Cruschina, Existentials and locatives in Romance dialects of Italy, 43-98. Oxford: Oxford University Press.

Diedrichsen, Elke. 2013. Auxiliary selection in German. Constructional gradience with perfect formation. In Elly van Gelderen, Michela Cennamo \& Jóhanna Barðdal (eds.), Argument structure in flux: the Naples/Capri papers, 405-434. Amsterdam \& Philadelphia: Benjamins.

Dixon, R. M. W. 1982. Where have all the adjectives gone?: and other essays in semantics and syntax. The Hague: Mouton.

Dowty, David R. 1979. Word meaning and Montague Grammar. Dordrecht: Reidel.

Dowty, David R. 1991. Thematic proto-roles and argument Selection. Language 67. 547-619.

Erteschik-Shir, Nomi. 1997. The dynamics of focus structure. Cambridge: Cambridge University Press.

Francez, Itamar. 2007. Existential propositions. Stanford: Stanford University thesis.

Francez, Itamar. 2010. Context dependence and implicit arguments in existentials. Linguistics and Philosophy 33 (1). 11-30.

Fuchs, A. 1980. Accented subjects in 'all-new' sentences. Wege zur Universalienforschung (Festschrift für Hansjakob Seiler), 449-461. Tübingen: Narr.

Givón, Talmy. 1976. Topic, pronoun and grammatical agreement. In Charles N. Li (ed.), Subject and topic, 149-188. New York: Academic Press.

Harris, Alice and Lyle Campbell. 1995. Historical syntax in crosslinguistic perspective. Cambridge: Cambridge University Press.

Hazout, Ilan. 2004. The syntax of existential constructions. Linguistic Inquiry 35. 393-430. Jackendoff, Ray (1976). Toward an explanatory semantic representation. Linguistic Inquiry 7. 89-150.

Keenan, Edward L. 1976. Towards a universal notion of "subject". In Charles N. Li (ed.), Subject and topic, 247-333. New York: Academic Press.

La Fauci, Nunzio and Michele Loporcaro. 1997. Outline of a theory of existentials on evidence from Romance. Studi italiani di linguistica teorica e applicata 26. 5-55.

Lambrecht, Knud. 1994. Information structure and sentence form. Topic, focus, and the mental representation of discourse referents. Cambridge: Cambridge University Press. 
Lambrecht, Knud. 2000. When subjects behave like objects: a markedness analysis of sentence focus constructions across languages. Studies in Language 24. 611-682.

Lehmann, Christian. 1982. Universal and typological aspects of agreement. In Hansjakob Seiler and Franz Joseph Stachowiak (eds.), Apprehension. Das sprachliche Erfassen von Gegenständen. Teil II. Die Techniken und ihr Zusammenhang in der Einzelsprachen, 201-267. Tübingen: Gunter Narr (LUS, 1, II).

Lehmann, Christian. 2014 [1982]. Universal and typological aspects of agreement. Available at http://www.christianlehmann.eu/publ/lehmann agreement.pdf (accessed March 2016).

Levin, Beth and Rappaport Hovav, Malka. 1995. Unaccusativity: at the syntax-lexical semantics interface. Cambridge, Mass.: The MIT Press.

Loporcaro, Michele. 1998. Sintassi comparata dell'accordo participiale romanzo. Turin: Rosenberg \& Sellier.

Maiden, Martin and Parry, Mair (eds). 1997. The dialects of Italy. London: Routledge.

Manzini, Maria Rita and Leonardo Savoia. 2005. I dialetti italiani e romanci. Morfosintassi generativa, 3 vols. Alessandria: Edizioni Dell'Orso.

Mithun, Marianne. 2003. Pronouns and agreement: the information status of pronominal affixes. Transactions of the Philological Society 101. 235-278.

Moravcsik, Edith. 1978. Agreement. In Joseph Greenberg (ed.), Universals of human language, vol. 4, 331-374. Stanford, Cal.: Stanford University Press.

Parry, Mair 1993. Piedmontese subject clitics. A diachronic perspective. Vox Romanica 52. 96-116.

Parry, Mair. 1997. Piedmont. In Martin Maiden and Mair Parry (eds.), The Dialects of Italy, 237-244. London: Routledge.

Parry, Mair. 2000. Accordo e soggetti postverbali in piemontese. In Actes du XXIIe congrès international de lingüistique e philologie romane, Bruxelles 1998, VI. De la grammaire des formes à la grammaire du sens, 391-402. Tübingen: Niemeyer.

Parry, Mair. 2005. Sociolinguistica e grammatica del dialetto di Cairo Montenotte. Parluma 'd Coiri. Savona: Società Savonese di Storia Patria.

Parry, Mair. 2013. Variation and change in the presentational constructions of North-Western Italo-Romance varieties. In Elly van Gelderen, Michela Cennamo and Jóhanna Barðdal (eds.), Argument structure in flux: The Naples/Capri papers, 511-548. Amsterdam \& Philadelphia: Benjamins.

Perlmutter, David. 1978. Impersonal passives and the Unaccusative Hypothesis. Berkeley Linguistic Society 4. 157-189.

Permultter, David. 1989. Multiattachment and the Unaccusative Hypothesis: the perfect auxiliary in Italian. Probus 1. 63-120.

Pinto, Manuela. 1997. Licensing and interpretation of inverted subjects in Italian. Utrecht: UiL OTS Dissertation series.

Poletto, Cecilia. 1993. La sintassi del soggetto nei dialetti italiani settentrionali. Padua: Unipress.

Poletto Cecilia. 2000. The higher functional field. Evidence from Northern Italian dialects. Oxford: Oxford University Press.

Poletto, Cecilia and Christina Tortora. 2016. Subject clitics: syntax. In Adam Ledgeway and Martin Maiden (eds.), Oxford guide to the Romance languages, 772-785. Oxford: Oxford University Press.

Renzi, Lorenzo and Laura Vanelli. 1983. I pronomi soggetto in alcune varietà romanze. In Paola Benincà, Manlio Cortelazzo, Aldo Prosdocimi, Laura Vanelli, \& Alberto Zamboni (eds.), Scritti linguistici in onore di Giovan Battista Pellegrini, 121-145. Pisa: Pacini. 
Rizzi, Luigi. 1986. On the status of subject clitics in Romance. In Osvaldo Jaeggli and Carmen Silva-Corvalan (eds.), Studies in Romance linguistics, 391-419. Dordrecht: Foris.

Roberts, Ian. 2014. Subject clitics and macroparameters. In Paola Benincà, Adam Ledgeway, and Nigel Vincent (eds.), Diachrony and dialects. Grammatical change in the dialects of Italy, 177-201. Oxford: Oxford University Press.

Rosemeyer, Malte. 2013. Tornar and volver. The interplay of frequency and semantics in compound tense auxiliary selection in Medieval and Classical Spanish. In Elly van Gelderen, Michela Cennamo and Jóhanna Barðdal (eds.), argument structure in flux: The Naples/Capri papers, 435-457. Amsterdam \& Philadelphia: Benjamins.

Saccon, Graziella. 1992. VP-internal arguments and locative subjects. Proceedings of the 22nd meeting of the North Eastern linguistic society. 383-397.

Saccon, Graziella 1993. Post-verbal subjects: a study based on Italian and its dialects. Cambridge, Mass: Harvard University thesis.

Samek-Lodovici, Vieri. 2002. Agreement impoverishment under subject inversion. A crosslinguistic analysis. In Gisbert Fanselow and Caroline Féry (eds.), Resolving conflicts in grammar (Linguistiche Berichte Sonderheft 11), 49-82.

Sasse, H-J. 2006. Theticity. In Giuliano Bernini and M. L. Schwartz (eds.), Pragmatic organization of discourse in the languages of Europe, 255-308. Berlin-New York: de Gruyter.

Savoia, Leonardo. 1997. The geographical distribution of the dialects. In Martin Maiden and Mair Parry (eds.), The dialects of Italy, 225-234. London: Routledge.

Schwartz, Linda. 1993. On syntactic and semantic alignment of attributive and identificational constructions. In Robert Van Valin Jr. (ed.), Advances in Role and Reference Grammar, 433-463. Amsterdam \& Philadelphia: Benjamins.

Siewierska, Anna. 1999. From anaphoric pronoun to grammatical agreement marker. Why objects don't make it. Folia Linguistica XXXII(2). 225-251.

Smith, Carlota. 1997. The parameter of aspect. Dordrecht: Kluwer.

Sorace, Antonella. 2000. Gradients in auxiliary selection with intransitive verbs. Language 76(4). 859-890.

Tortora, Christina. 1997. The syntax and semantics of the weak locative. Delaware: University of Delaware thesis.

Tortora, Christina. 2014. A comparative grammar of Borgomanerese. New York: Oxford University Press.

Vanelli, Laura. 1997. Personal pronouns and demonstratives. In Martin Maiden and Mair Parry (eds.), The dialects of Italy, 106-115. London: Routledge.

Van Valin, Robert Jr. 1990. Semantic parameters of split intransitivity. Language 66. 221260.

Van Valin, Robert Jr. 2005. Exploring the syntax-semantics interface. Cambridge: Cambridge University Press.

Van Valin, Robert Jr. and Randy LaPolla. 1997. Syntax. Structure, meaning and function. Cambridge: Cambridge University Press.

Vendler, Zeno. 1967. Linguistics in philosophy. Ithaca, N. Y.: Cornell University Press.

Wehr, Barbara. 1984. Diskursstrategien in Romanischen. Tübingen: Narr.

Wehr, Barbara. 199. SE-Diathese in Italienischen. Tübingen: Narr.

Zamparelli, Roberto. 2000. Layers in the Determiner Phrase. New York: Garland.

Zeller, Jochen. 2013. Locative inversion in Bantu and predication. Linguistics 51. 1107-1146. 